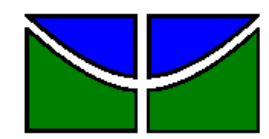

Universidade de Brasília

Faculdade de Economia, Administração e Contabilidade

Departamento de Administração

Curso de Graduação em Administração a distância

MATHEUS DE ANDRADE SANTANA

\title{
ENDOMARKETING: Um estudo de Caso na Agência de um Banco Público da cidade de Paraíso do Tocantins.
}

Brasília - DF 


\section{MATHEUS DE ANDRADE SANTANA}

\section{ENDOMARKETING: Um estudo de Caso na Agência de um Banco Público da cidade de Paraíso do Tocantins.}

Monografia apresentada a Universidade de Brasília (UnB) como requisito parcial para obtenção do grau de Bacharel em Administração.

Professor Orientador: Prof. Eraldo Ricardo dos Santos

$$
\text { Brasília - DF }
$$


Santana, Matheus de Andrade.

Endomarketing: Um estudo de Caso na Agência Paraíso de uma instituição Financeira / Matheus de Andrade Santana. - Brasília, 2011.

$58 \mathrm{f}$ : : il.

Monografia (bacharelado) - Universidade de Brasília, Departamento de Administração - EaD, 2011.

Orientador: Prof. Eraldo Ricardo dos Santos, Departamento de Administração.

1. Endomarketing. 2. Motivação. 3. Treinamento. 4. Comunicação Interna. 5. Cultura Organizacional. 6. Clima organizacional. 7. Liderança. 8. O papel do gerente na perspectiva do Endomarketing. I. Título. 


\title{
MATHEUS DE ANDRADE SANTANA
}

\section{ENDOMARKETING: Um estudo de Caso na Agência de um Banco Público da cidade de Paraíso do Tocantins.}

\begin{abstract}
A Comissão Examinadora, abaixo identificada, aprova o Trabalho de Conclusão do Curso de Administração da Universidade de Brasília do aluno.
\end{abstract}

\section{Matheus de Andrade Santana}

Adm. Eraldo Ricardo dos Santos

Professor-Orientador

Adm. Eraldo Ricardo dos Santos, Professor-Examinador
Tutor, Roberto Tenório

Professor-Examinador 
A meus pais, Agostinho e Beranice, pelos exemplos de superação e perseverança que mudaram a minha vida.

A minha noiva Paula pela presença constante em todos os momentos importantes. 


\section{AGRADECIMENTOS}

À Universidade de Brasília.

À Coordenação do Curso de Graduação em Administração a Distância.

Ao Banco do Brasil S/A.

Ao tutor Eraldo, pela paciência, pela atenção, pelo acompanhamento, pelo entusiasmo e força repassados durante o desenvolvimento do estudo. 
"O homem é um ser em ação, que elabora planos e dirige os seus movimentos com o objetivo de alcançar determinados fins. A escolha desses fins não é feita por acaso, mas em função do que o homem considera importante a sua vida, de acordo com os valores que elege".

Paulo Nader 


\section{RESUMO}

O presente estudo tem como objetivo avaliar as ações e ferramentas de endomarketing utilizadas na agência de um banco público na cidade de Paraíso do Tocantins, utilizando os conceitos de endomarketing para melhorar o seu desempenho e atingir seus objetivos organizacionais, além de avaliar os meios de comunicação, as lideranças, o clima organizacional na agência e a motivação e comprometimento dos funcionários. Para tanto, através de pesquisa bibliográfica procura contextualizar o tema endomarketing e assuntos correlatos tais como: comunicação, motivação e satisfação no trabalho, liderança, cultura e clima organizacional. $\mathrm{O}$ trabalho consiste em uma pesquisa descritiva que utiliza as formas de estudo de caso e pesquisa documental. Após a entrevista com os funcionários, os dados foram tabulados e criticados. Os resultados apontam que os conceitos de endomarketing são praticados na Agência Paraíso. A pesquisa de satisfação com relação aos meios de comunicação revelou-se de modo geral que os funcionários estão satisfeitos com a funcionalidade e usabilidade das ferramentas, embora alguns meios de comunicação precisem ser revistos de modo a corrigir desvios. Com relação à motivação revelou-se de modo geral que os funcionários estão motivados e comprometidos com as metas e objetivos da agência. Em relação ao treinamento, revelou-se que os funcionários se utilizam com maior freqüência de cursos na modalidade auto-instrucional para aprimoramento, porém a pesquisa constatou que o tempo disponibilizado semanalmente para treinamento é insatisfatório. A pesquisa de clima organizacional seguiu a mesma tendência da pesquisa de motivação, ao revelar que a agência apresenta um clima organizacional satisfatório, com administração participativa e lideranças abertas ao diálogo. Como oportunidades de melhoria do desempenho o trabalho recomenda: a disponibilização de um ambiente adequado para o estudo de cursos auto-instrucionais em agência; a correção nos desvios apresentados em alguns meios de comunicação como a central de atendimento e o aplicativo resolve. Melhor aproveitamento da TV institucional e melhor divulgação da disponibilidade e importância do uso do email coorporativo.

Palavras-chave: Endomarketing, Motivação, Treinamento, Liderança, Cultura Organizacional e Clima organizacional. 


\section{LISTA DE GRÁFICOS}

Gráfico 1 - Nível de escolaridade dos funcionários ........................................38

Gráfico 2 - Satisfação com Aplicativo Responde............................................40

Gráfico 3 - Nível de Motivação dos funcionários I ..............................................43

Gráfico 4 - Nível de Motivação dos funcionários II ...........................................43

Gráfico 5 - Treinamentos mais utilizados .................................................4 44

Gráfico 6 - Treinamentos com melhor aproveitamento .....................................45

Gráfico 7 - Período de treinamento presencial ............................................46 


\section{LISTA DE TABELAS}

Tabela 1 - Fórmula de apuração dos resultados ............................................36

Tabela 2 - Perfil do quadro pessoal - funções ............................................. 37 


\section{LISTA DE ABREVIATURAS E SIGLAS}

AMA - American Marketing Association

CORREIO - Aplicativo de envio de mensagens coorporativas

DIPES - Diretoria de Gestão de Pessoas

GEPES - Gerência de Gestão de Pessoas

IN - Instruções Normativas

LIC - Livro de instruções Codificadas

MS-DOS - Sistema Operacional

PAVAS - Programa de Assistência às Vítimas de Assalto e Sequestro

PCMSO - Programa de Controle Médico da Saúde Ocupacional

PLD - Prevenção e combate à lavagem de dinheiro

SESMT - Serviços Especializados em Engenharia de Segurança e em Medicina do

Trabalho

TABAS - Programa de Controle do Tabagismo

TAO - Talentos e oportunidade 


\section{SUMÁRIO}

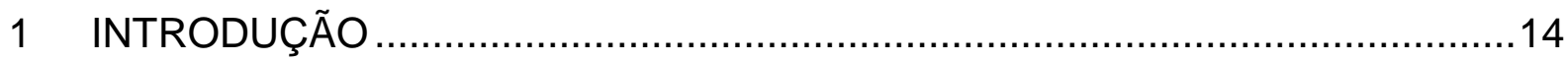

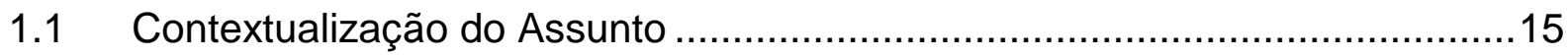

1.2 Formulação do problema...................................................................16

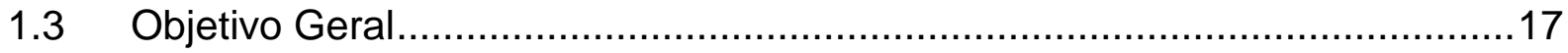

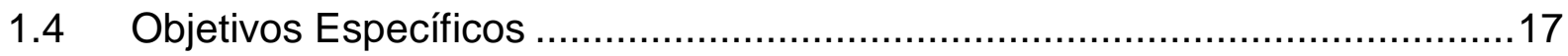

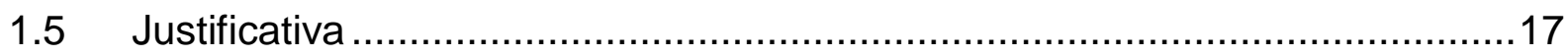

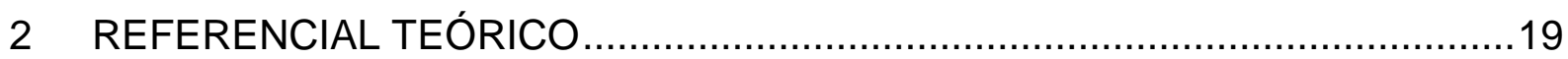

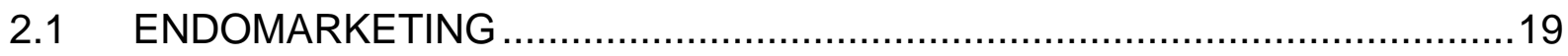

2.1.1 Origem, Conceito, Objetivo e Função …………………………….........19

2.1.2 Relação Estratégica com Marketing....................................................21

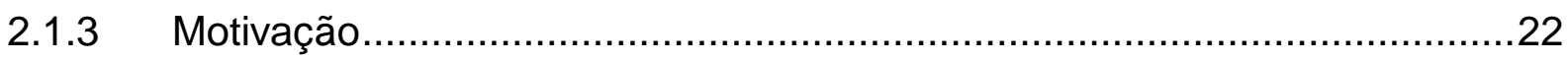

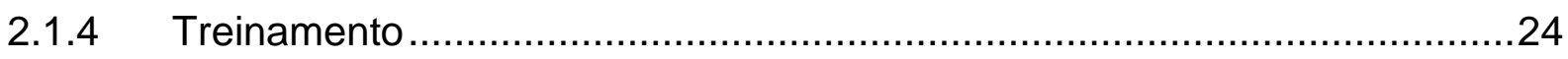

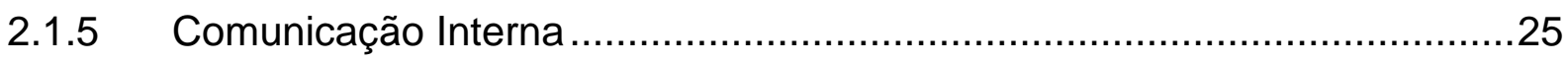

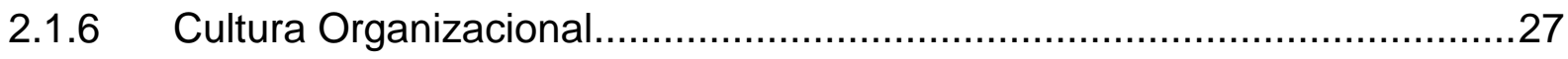

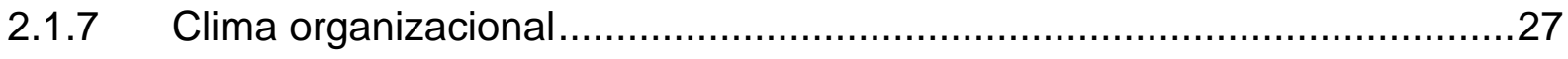

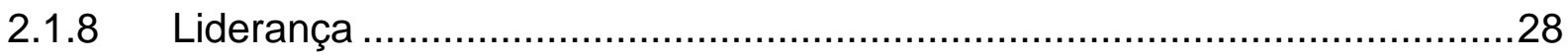

2.1.9 O papel do gerente na perspectiva do endomarketing.............................29

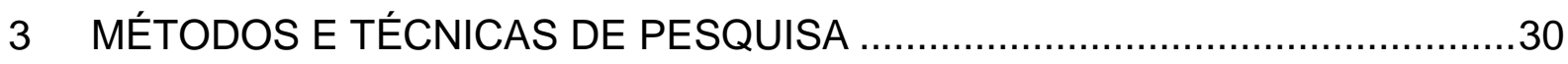

3.1 Tipo e descrição geral da pesquisa …………..........................................33

3.2 Caracterização da organização, setor ou área do objeto de estudo................34

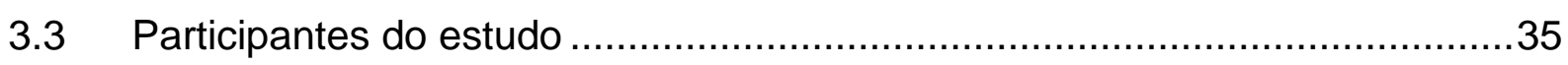

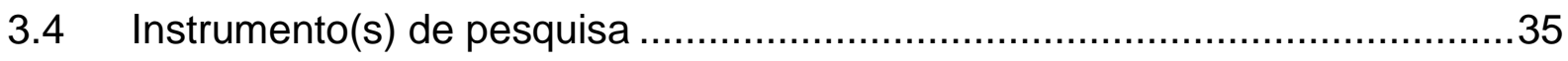

3.5 Procedimentos de coleta e de análise de dados .........................................35

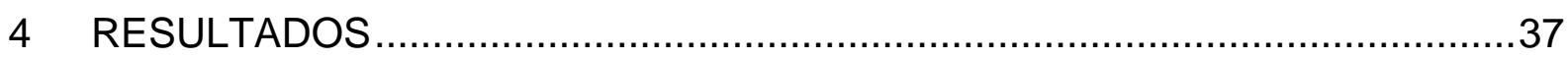

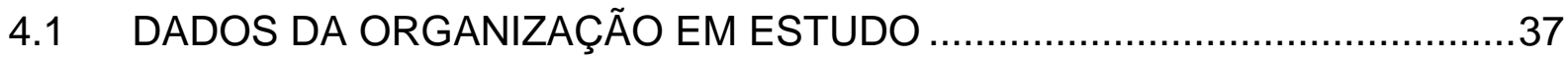




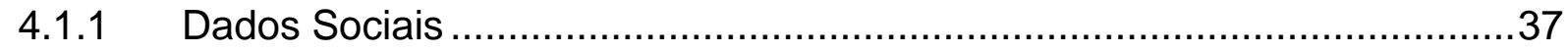

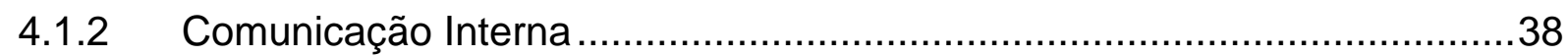

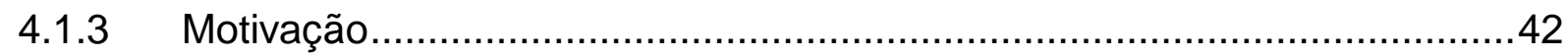

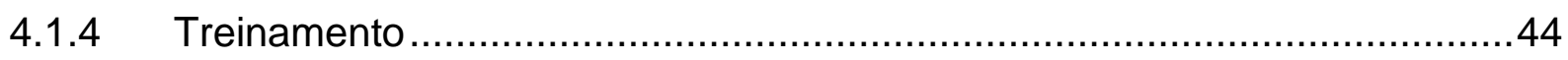

4.1.5 Cultura/Clima Organizacional e Liderança......................................46

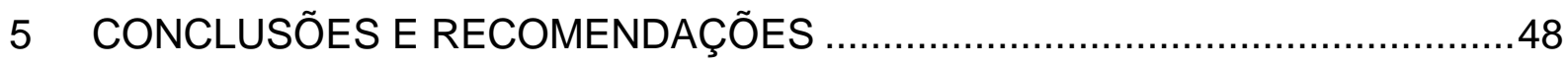

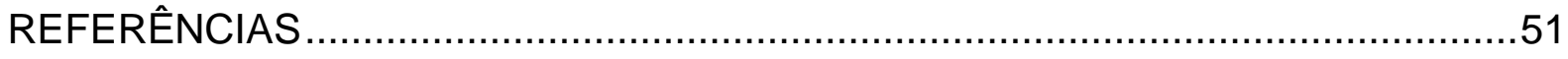

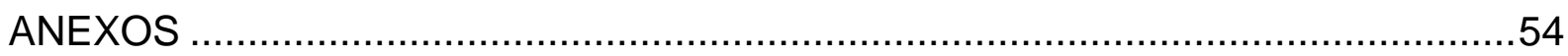

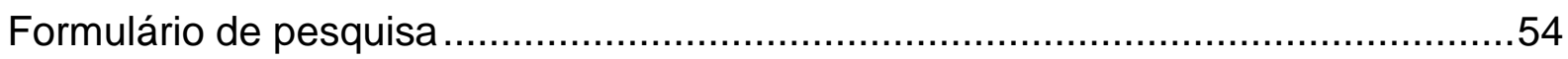




\section{INTRODUÇÃO}

Com o crescimento do setor bancário no Brasil e o aumento da concorrência, aliado a oferta em demasia de produtos e serviços cada vez mais parecidos, faz com que os bancos busquem um diferencial competitivo.

O atendimento é um dos principais diferenciais competitivos, pois um bom atendimento garante a fidelidade e satisfação dos clientes, segundo Kotler (1998), a satisfação aliada ao bom atendimento é o aspecto que faz o cliente retornar, por isso, a satisfação do cliente tem que ser o motivo maior, pois estes quando satisfeitos são mais do que simples consumidores ou clientes, mas, parceiros comerciais e advogados que defendem a empresa e fazem propaganda para amigos e familiares.

A qualidade no atendimento está diretamente ligada ao corpo funcional, que por sua vez, devem estar motivados e alinhados com as estratégias e objetivos da organização. A partir dessa necessidade de se motivar e comprometer os funcionários surgiu o endomarketing ou marketing interno.

O endomarketing ou marketing interno é uma ramificação do marketing, segundo Kotler (1998), marketing é um processo social por meio do qual pessoas e grupos de pessoas obtêm aquilo de que necessitam e o que desejam com a criação, oferta e livre negociação de produtos e serviços de valor com outros".

A definição de marketing adotada pela AMA - American Marketing Association (2007), entidade que congrega profissionais e especialistas na matéria, é a seguinte: "Marketing é a atividade, o conjunto de instituições e os processos para criar, comunicar, entregar e trocar ofertas de valor para consumidores, clientes, parceiros e a sociedade em geral".

As duas definições mostram que o processo de marketing envolve a criação, a oferta, a livre negociação e a entrega de valor para outros.

O Endomarketing ou Marketing Interno surgiu da necessidade de se motivar pessoas para os programas de mudança organizacional, que começaram a ser implantados em grandes empresas multinacionais a partir da década de 1950. Emergiu como resposta à globalização e à necessidade de adaptação das empresas. Esta evolução remete a dicotomia entre marketing centrípeto e marketing centrífugo. Enquanto o marketing centrípeto canaliza a sua atenção para 0 
endomarketing, o marketing centrífugo utiliza-se do marketing centrípeto para agregar valor ao produto e/ou diferenciar a prestação do serviço, realçando a posição estratégica competitiva da empresa. A força do marketing centrípeto considera que as pessoas que trabalham na organização são responsáveis pelos serviços prestados, pelos produtos oferecidos e são cobrados constantemente por padrões de qualidade. Desta forma, surge a importância de se criar mecanismos que atendam às necessidades dos funcionários, desenvolvam uma imagem positiva da empresa frente ao público interno e melhorem o processo de comunicação.

Dada a importância estratégica do endomarketing nas organizações e amplitude do tema, irei focar nesse estudo, o endomarketing como diferencial estratégico para melhoraria da comunicação, treinamento, motivação, satisfação e comprometimento dos funcionários.

\subsection{Contextualização do Assunto}

O endomarketing ou marketing interno é realizado entre a empresa e seus funcionários. Segundo Bekin (1995), "o endomarketing consiste em ações de marketing voltadas ao público interno da empresa, com o fim de promover entre seus funcionários e departamentos valores destinados a servir o cliente". Objetiva facilitar e realizar trocas construindo relacionamentos com os funcionários, compartilhando os objetivos da empresa ou organização, harmonizando e fortalecendo estas relações.

Cobra \& Ribeiro (2000) destacam, por exemplo, que o marketing interno considera funcionários e intermediários que trabalham para a organização como um alvo. A idéia que apóia o conceito é que não é possível fazer marketing externo sem o compromisso do corpo de funcionários com o principal objetivo da organização que é criar e manter clientes.

Cerqueira (1994) afirma que, endomarketing são projetos e ações através dos quais a organização consegue obter maior comprometimento dos empregados. Essas ações e empreendimentos, na sua visão, devem ter como foco a valorização e reconhecimento das pessoas, canais adequados de comunicação interpessoal, 
administração participativa, e obtenção de índices maiores de produtividade e qualidade com conseqüente redução de custos.

Dentro dessa perspectiva, o estudo irá avaliar se a agência de um banco público localizada na cidade de Paraíso do Tocantins utiliza as ferramentas e desenvolve as ações de endomarketing disponibilizadas pelo banco para promover a comunicação, treinamento, motivação, comprometimento e satisfação dos funcionários, de modo a promover um clima organizacional agradável que favoreça o alcance das metas e objetivos da agência e do banco.

Durante o estudo, o nome do banco público cuja agência será analisada, não será mencionado devido à condição imposta pelo banco para realização da pesquisa.

\subsection{Formulação do problema}

Considerando a concorrência do setor bancário e a necessidade de diferenciação dos demais concorrentes, o ativo humano (funcionários) torna-se um diferencial competitivo importante para o alcance dos resultados, o que nos remete a necessidade de se manter os funcionários motivados, treinados e em sintonia com o posicionamento estratégico da instituição financeira.

Os principais objetivos do endomarketing são: Manutenção de um ambiente de trabalho, que proporcione motivação, valorização e reconhecimento das pessoas; Aumento dos índices de produtividade e qualidade com a diminuição dos custos; Criação de canais de comunicação entre todos, independente do nível hierárquico, para a eliminação de conflitos interpessoais e também para trocas de experiências, gerando assim uma melhoria nos relacionamentos (KOTLER, 1993, p.417).

A partir desse contexto, chego aos seguintes questionamentos: Qual o posicionamento estratégico do banco público, dentro do conceito de endomarketing, para melhoria da motivação, treinamento e comunicação? Quais as ferramentas e ações utilizadas para fomentá-las? E qual a efetividade dessas ferramentas e ações na agência da cidade de Paraíso do Tocantins? 


\subsection{Objetivo Geral}

O presente estudo tem por objetivo avaliar a efetividade das ferramentas e ações de endomarketing utilizadas pelo banco público na agência da cidade de Paraíso do Tocantins para promover a comunicação, treinamento, motivação, comprometimento e satisfação dos funcionários, visando melhoria do clima organizacional e consequentemente do atendimento e resultado da agência.

\subsection{Objetivos Específicos}

Para alcançar o objetivo geral deste estudo, irei identificar quais as ações e ferramentas de endomarketing são atualmente utilizadas pelo banco público para fomentar a motivação, a cultura de treinamento e a comunicação. Avaliar o grau de comprometimento e liberdade dos funcionários nas decisões que afetam suas atividades, avaliar o clima organizacional, identificar iniciativas e ações de endomarketing desenvolvidas pela agência e avaliar o grau de motivação expressado pelos funcionários.

\subsection{Justificativa}

O crescimento do setor bancário e a popularização do crédito e dos serviços bancários (cartões, seguros, capitalização, etc.), aliado a oferta em demasia de produtos e serviços cada vez mais idênticos, faz com que as empresas do setor busquem agregar algum diferencial competitivo aos seus produtos ou serviços. $O$ atendimento é um importante diferencial competitivo, e está diretamente ligado a satisfação, treinamento e motivação dos funcionários.

Mesmo que o banco possua políticas de endomarketing consolidadas, com canais definidos de comunicação e treinamento, quando não se avalia constantemente o nível de motivação e comprometimento dos funcionários das 
agências, não é possível identificar se as ações e ferramentas de endomarketing estão sendo efetivas.

A aplicação efetiva de uma política de endomarketing no contexto de uma agência bancária traz impacto positivo aos funcionários mesmo em períodos de transição, como mudanças estratégicas, lançamento de novos produtos, mudanças de sistemas de trabalho etc., CARVALHO (1997), afirma: "As principais atitudes são: estabelecer as prioridades e criar um sentimento positivo e de disciplina, promover nos funcionários um nível de comprometimento necessário, bem como o engajamento e a confiança para que os trabalhadores possam enfrentar esse período de transição e inspirar um sentimento de propósito, de coerência e de responsabilidade para que todos permaneçam focados e engajados no trabalho".

Por esse motivo, torna-se evidente a necessidade de se avaliar a efetividade das ferramentas utilizadas pelo banco público para promover a comunicação, treinamento, motivação, comprometimento e satisfação dos funcionários. 


\section{REFERENCIAL TEÓRICO}

\subsection{ENDOMARKETING}

\subsubsection{Origem, Conceito, Objetivo e Função}

Endomarketing é a aplicação e adaptação de técnicas e princípios de Marketing, que são voltadas para o interior das organizações, observando condutas de responsabilidade socioambiental. O sentido de algo para dentro, de interiorização, é dado pelo próprio significado de endo que tem sua origem do prefixo grego "éndon", que significa movimento para dentro. A palavra inglesa Marketing, que não tem tradução exata em língua portuguesa, mas é muito conceituada por diversos autores nacionais e estrangeiros.

Para Kotler (1998, p.27) "Marketing é um processo social e gerencial pelo qual indivíduos e grupos obtêm o que necessitam e desejam através da criação, oferta e troca de produtos de valor com outros". Podemos evidenciar que essa definição baseia-se nos conceitos centrais de necessidades, desejos e demandas, não há uma clara definição da atuação do Marketing unicamente para o exterior da empresa.

É fundamental a participação de todos os funcionários na busca da satisfação dessas necessidades, desejos e demandas, conforme enunciado por Lambert (1996), ao deixar explícito que todos na organização devem estar dedicados ao Marketing ou não se terá nenhum Marketing. Assim, cada colaborador deve estar consciente da importância de direcionar todos os esforços para servir bem ao cliente.

O marketing interno deve preceder o marketing externo, segundo Kotler (1998, p. 40) que conceituou o marketing interno como uma tarefa de êxito de contratar, treinar e motivar os funcionários, para que eles possam bem atender ao cliente. 
O Endomarketing ou Marketing Interno é aplicação e adaptação de técnicas e ferramentas de Marketing para atingir o público interno da organização. Através da aplicação do Marketing, internamente, a empresa estaria se qualificando para o cliente externo.

$\mathrm{Na}$ visão de Berry (apud Las Casas, 2000), o Marketing Interno estabelece o empregado como sendo o cliente e os cargos como sendo os produtos, que têm que atender às necessidades dos clientes internos, ao mesmo tempo em que a organização procura alcançar seus objetivos.

Para Brum (1994, p.19-23), Endomarketing é "um conjunto de ações de Marketing para o público interno. São ações que a empresa deve utilizar adequadamente para vender sua imagem aos funcionários e familiares". Bekin (1995) conceitua Endomarketing como "um processo cujo foco é sintonizar e sincronizar, para implementar e operacionalizar a estrutura de Marketing da empresa ou organização que visa ação para mercado". O objetivo é atrair e reter o cliente interno, fortalecendo as relações empresa-empregado e com a função de integrar a noção de cliente nos processos internos da estrutura organizacional para proporcionar melhorias substanciais na produtividade e na qualidade dos produtos e serviços ofertados. Com essa nova concepção, o Marketing deixa de ser somente função da Diretoria de Marketing da organização e passa a estar presente em todos os setores da empresa, desde a área de desenvolvimento e produção do produto até o pessoal da linha de frente.

Endomarketing são projetos e ações através dos quais a organização consegue obter maior comprometimento dos empregados. As ações e empreendimentos, na sua visão, devem ter como foco a valorização e reconhecimento das pessoas, canais adequados de comunicação interpessoal, administração participativa, e obtenção de índices maiores de produtividade e qualidade com conseqüente redução de custos (CERQUEIRA, 1994). Assim, a valorização e reconhecimento das pessoas têm como cunho o estímulo e motivação para o trabalho. Neste sentido, Brum (1998), por exemplo, detalha algumas causas que poderiam levar as pessoas a ficarem desmotivadas no trabalho: salário inadequado, má comunicação empresarial, falta de programas de avaliação e de promoção por merecimento, trabalho excessivo ou mesmo inexistência das condições necessárias para a execução das tarefas. 
Desta forma, um programa de Endomarketing abrangente poderia se preocupar e tratar destas questões, entre outras, no sentido de aumentar o nível motivacional dos empregados. Na definição de Inkote (2000, p.85), o Endomarketing é "a adaptação e utilização de técnicas, instrumentos e conceitos de Marketing para atingir específico segmento de mercado de clientes, que têm como característica comum o trabalho em uma mesma organização". Como conceito, Inkote (2000) diz que o Endomarketing "consiste em identificar as necessidades e desejos a partir do próprio cliente interno, para satisfazê-lo eficaz e eficientemente, buscando o estímulo à compra (do produto-empresa) e a fidelização deste segmento".

São exemplos de valores para os empregados o estabelecimento de uma clara ideologia corporativa, o relacionamento gerentes/subordinados, a flexibilidade, a satisfação com o trabalho realizado, os benefícios e uma remuneração competitiva. Usando tal conhecimento, a empresa pode fortalecer sua proposta de valor para os empregados direcionando-a a segmentos funcionais, da mesma forma que o marketing externo opera em relação à segmentação de clientes.

\subsubsection{Relação Estratégica com Marketing}

O Endomarketing possui uma relação estratégica com o marketing, não podendo ser desvinculado dele. Kotler (1998) afirma que "o marketing interno deve preceder o marketing externo". Quando uma organização elabora um plano de marketing, ela avalia o atual cenário do mercado que pretende explorar. Para tal, faz-se uma pesquisa para identificar necessidades não satisfeitas do cliente, analisa-se o ambiente econômico, tecnológico, social, cultural e governamental do cenário externo. Porém, todo esse trabalho corre o risco de ser subaproveitado, pelo fato de estar incompleto porque a organização não avaliou o ambiente interno.

É nesse aspecto que se estabelece a relação estratégica do Endomarketing com o Marketing, pois enquanto o marketing volta-se para o ambiente externo, cabe ao endomarketing ocupar-se do ambiente interno realizando a ação estratégica de orientação dos funcionários.

A avaliação do ambiente interno é tão importante quanto à avaliação do ambiente externo. Os funcionários são a parte propulsora do sucesso, é preciso conquistar primeiro o mercado dos clientes internos para depois lançar-se no 
mercado externo. Não podemos partir do pressuposto de que todos vestem a camisa da empresa, pois isso quase sempre não é verdade. Todos que estão no negócio têm de participar do negócio, conhecê-lo, estar ciente dele para que funcione da melhor maneira possível.

\subsubsection{Motivação}

A motivação é um processo global que tem como objetivo final comprometer o funcionário com as causas e objetivos da empresa para integrá-lo à cultura organizacional. Este comprometimento implica o aprimoramento do desempenho do funcionário por meio de sua valorização e de sua satisfação como indivíduo que pertence a uma organização (BEKIN, 1995).

Ainda segundo Bekin (1995), de acordo com essa perspectiva, todo processo de motivação forma uma seqüência constituída pelas seguintes etapas: estímulo, esforço, desempenho, valorização, recompensa, satisfação e comprometimento. E complementa afirmando que cada etapa desta seqüência tem uma função precisa e deve ser acionada para que o processo de motivação como um todo seja bemsucedido. As etapas formam um encadeamento necessário. Podemos compará-las ao corpo humano e seus membros. Ignorar qualquer uma delas significa mutilar este corpo e prejudicar o processo de motivação.

Freud (apud Casado, 2002) entende que o instinto exerce uma pressão determinada por sua força e pela intensidade da necessidade subjacente. $O$ instinto é o propulsor da personalidade e a forma de energia pela qual os instintos realizam sua tarefa chama-se libido. O deslocamento da libido no sentido de buscar a satisfação das necessidades e reduzir a tensão age como força motivadora permanente do comportamento humano, ou seja, para Freud, a motivação depende da intensidade dos motivos e varia de indivíduo para indivíduo.

Nessa sentido, Hersey e Blanchard (1982) preconizam que os motivos podem ser definidos como necessidades, desejos ou impulsos que partem dos indivíduos e orientam o comportamento das pessoas para o atingimento de objetivos, que podem ser conscientes ou inconscientes.

Paladini (1990) descreve três momentos nas abordagens motivacionais, até se chegar à visão atual. O primeiro momento ocorre com a descoberta de que o medo 
não constitui fator de motivação e que sua eliminação também não a promove, criando-se apenas uma lacuna. No segundo momento surge o conceito de motivação atrelada à satisfação de necessidades, que também se mostrou inadequada, pois gera uma atitude de acomodação, quando se espera um desempenho ativo das pessoas. A visão atual está vinculada ao conceito de automotivação das pessoas, no qual estas passam a envolverem-se com aquilo que fazem, respondendo por sua ação.

A motivação está relacionada às ações empreendidas pelo indivíduo com o objetivo de alcançar a estabilidade interna. Os objetivos às vezes são chamados de recompensas esperadas, para as quais se dirigem os motivos. Gerentes que conseguem motivar seu pessoal com êxito são aqueles capazes de criar um ambiente com objetivos (incentivos) compatíveis com os motivos (necessidades) específicos dos seus funcionários (HERSEY e BLANCHARD, 1982).

Considerando que o tema motivação para o trabalho esta diretamente relacionado ao Endomarketing, tendo em vista a necessidade de se conquistar e preservar o cliente interno, pois, identificar e melhor atender as expectativas dos funcionários é objeto principal de pesquisa, análise e ação do Endomarketing.

O Banco público cuja agência é alvo do estudo, como forma de motivação oferece a seus funcionários a possibilidade de administrarem sua trajetória profissional e de planejarem sua carreira. Dispõe de um Programa de Ascensão Profissional e de um Banco de Talentos e Oportunidades (TAO), por meio dos quais identifica os funcionários mais capacitados para o exercício das diferentes funções na empresa. Sobre as remunerações e benefícios, os funcionários do banco dispõem de vários benefícios além da remuneração básica (salário), como: previdência complementar, plano de saúde, participação nos lucros e capacitação profissional.

Ainda sob a perspectiva motivacional, o Banco possui em sua estrutura a Área de Qualidade de Vida no Trabalho, que desenvolve e gerencia vários programas que visam à melhoria na qualidade de vida dos funcionários, tais como: Programa de Controle Médico da Saúde Ocupacional - PCMSO, Serviços Especializados em Engenharia de Segurança e em Medicina do Trabalho - SESMT, Programa de Controle do Tabagismo - TABAS, Programa de Assistência às Vítimas de Assalto e Sequestro - PAVAS, Programa de Reconhecimento de Funcionários e Programa de Qualidade de Vida no Trabalho. 


\subsubsection{Treinamento}

O Treinamento é um processo de assimilação cultural a curto prazo, que objetiva repassar ou reciclar conhecimento, habilidades ou atitudes relacionadas diretamente à execução de tarefas ou à sua otimização no trabalho (MARRAS 2001, p. 145).

De acordo com Chiavenato (1999, p. 294) "O treinamento é uma maneira eficaz de delegar valor às pessoas, à organização e aos clientes. Ele enriquece o patrimônio humano das organizações".

O sistema de educação corporativa da instituição financeira existe desde 1965. Ao longo desse tempo, vem sendo oferecidas oportunidades de desenvolvimento pessoal e profissional a todos os funcionários.

Os programas e ações de aprendizagem fundamentam-se em princípios filosóficos e organizacionais e orientam-se pelos seguintes propósitos:

- Desenvolver a excelência humana e profissional dos funcionários, contribuindo com sua empregabilidade e capacitando-os para processos de ascensão profissional;

- Dar suporte ao desempenho profissional;

- Aperfeiçoar a performance organizacional, tornando a empresa competitiva; e

- Formar sucessores para quadros técnicos e gerenciais do Banco.

A produção e o acesso ao conhecimento são ancoradas na estratégia da empresa e nas várias possibilidades de carreira. Os meios usados são:

- Treinamentos presenciais, oferecidos nas GEPES Regionais;

- Aprendizagem por meio de diversas tecnologias educacionais, presenciais e a distância (mídia impressa, vídeo, TV Corporativa, Treinamento Baseado em Computador - TBC, web);

- Programas em parceria com as melhores instituições de ensino do País;

- Consultas às bibliotecas do Banco, com acesso a livros, periódicos especializados, banco de vídeos, bancos de teses, dissertações e monografias;

- Portal virtual que permite acessar publicações digitalizadas, biblioteca virtual, trilhas de desenvolvimento profissional, treinamentos on-line, etc.

As ações de capacitação estão organizadas em três grandes vertentes:

Programas de Formação Superior e de Apoio à Formação Superior 
- Bolsas de Graduação

- Bolsas de pós-graduação lato sensu, em nível de especialização

- Bolsas de pós-graduação stricto sensu - mestrado e doutorado

- Idiomas à distância

\section{Programa de Aprimoramento dos Funcionários}

- Ações de orientação profissional

\section{Programas de Educação Empresarial}

- Cursos

- Ciclo de Palestras

- Treinamento no exterior (preparação de gestores da área internacional)

- Outros eventos de atualização profissional

A Universidade Corporativa existe desde 2002, e foi criada com o objetivo de auxiliar os funcionários do Banco a descobrir e desenvolver seus talentos, crescer profissionalmente e contribuir para o bom desenvolvimento dos negócios.

No Portal da Universidade Corporativa são divulgadas as ações de desenvolvimento pessoal e profissional disponíveis e realizados treinamentos na modalidade a distância. O portal pode ser acessado tanto pela Intranet Corporativa como pela Internet.

Como suporte ao ensino e a aprendizagem, o Banco dispõe de unidades de informação corporativa (bibliotecas) que coordenam as atividades de prospecção, gestão e disseminação da informação e do conhecimento. $O$ acervo total das unidades de informação é composto por mais de 250 mil volumes com ênfase nas áreas de negócios do Banco. Conta, ainda, com títulos de outras áreas que contribuem para a formação integral do ser humano.

O Programa Ascensão Profissional para a Rede de Agências, iniciado em 2006, fornece subsídios para a gestão de carreira do funcionário e envolve ações de recrutamento, seleção, comissionamento e orientação profissional. É composto por 3 etapas - Certificação, Qualificação e Comissionamento. No âmbito do Programa PróEqüidade de Gênero, uma das ações do Banco é dar visibilidade aos indicadores de gênero de seus programas de ascensão profissional.

\subsubsection{Comunicação Interna}


A comunicação empresarial é um dos fatores mais importantes a ser considerado em qualquer programa de Endomarketing e traz reflexos imediatos e profundos no relacionamento entre empresa e funcionários.

As redes de comunicação constituem os canais por onde passa a informação. Caracterizam-se como redes formais e informais. As primeiras geralmente veiculam conteúdos técnico-administrativos e costumam ser centralizadas e verticais, obedecendo às diretrizes da organização. Já as redes informais, fluem por meios informais em qualquer direção da empresa, sem, necessariamente, ter que obedecer a níveis de autoridade (CASADO, 2002).

Para Brum (1998), comunicação interna é um conjunto de ações e de instrumentos utilizados pelas organizações para influenciar de forma positiva seus funcionários. Dentro desse contexto, é importante que a informação percorra os caminhos corretos e encontre o público certo, através de adequados instrumentos de distribuição. Brum construiu uma pirâmide organizacional, onde situa a informação com sua origem no topo, ou seja, nos altos níveis da direção, sendo disseminadas nos demais níveis - chefias intermediárias e demais funcionários sob a responsabilidade de quem cria e detêm o produto da comunicação.

A comunicação empresarial voltada para o público interno das organizações (diretoria, gerências e funcionários), busca informar os diversos segmentos desse público aos objetivos e interesses organizacionais, englobando comunicação administrativa (memorandos, cartas-circulares, instruções), comunicação social (boletins, jornais internos, vídeos-jornais, revistas) e a comunicação interpessoal. Os fluxos da comunicação podem ser de fluxo ascendente, fluxo descendente e fluxo horizontal, prevalecendo, porém, o fluxo descendente (CURVELLO, 2002).

O Banco possui meios de comunicação bem definidos e incorporados a sua estratégia coorporativa, a intranet é a plataforma de sustentação de alguns dos principais meios de comunicação utilizados durante a execução das tarefas diárias, tais como: Agência de notícias, email coorporativo, instruções normativas e revista institucional (versão web). Alguns meios de comunicação ainda são disponibilizados via sistema operacional MS-DOS, como o aplicativo Responde e o aplicativo Correio que está sendo substituído pelo Email Coorporativo.

O Banco disponibiliza na intranet o site "negociação coletiva" e um blog específico sobre o tema, visando o aprimoramento do processo de comunicação interna em prol da consolidação e disseminação da cultura do diálogo com as 
entidades sindicais, ampliando a interação e o debate sério dos temas envolvidos no processo entre a empresa e seus funcionários.

\subsubsection{Cultura Organizacional}

Segundo Schein (1986), cultura organizacional é um padrão de pressupostos básicos compartilhados os quais o grupo adquiriu à medida que resolveu seus problemas de adaptação externa e integração interna, e que funciona suficientemente bem para ser considerada válida. Portanto, essa experiência pode ser ensinada aos novos integrantes como forma correta de perceber, pensar e sentir-se em relação a esses problemas.

A cultura organizacional produz comportamentos funcionais que contribuem para que se alcancem as metas da organização. É também uma fonte de comportamentos desajustados que produzem efeitos adversos ao sucesso da organização (Robbins 1996). Uma função importante da cultura organizacional é distinguir uma organização de outras e de seu ambiente, proporcionando a esta uma identidade externa.

\subsubsection{Clima organizacional}

Clima organizacional é a qualidade do ambiente que é percebida ou experimentada pelos funcionários da organização e que influencia o seu comportamento. Morgan (1996) compara metaforicamente as organizações a seres vivos, fazendo um paralelo entre moléculas e indivíduos, células e grupos, organismos complexos e organizações. Assim sendo, uma das implicações mais imediatas de se considerarem as organizações como se fossem organismos vivos é, então, tentar descobrir suas necessidades ou carências, pois, além dessas carências fazerem parte integrante do todo organizacional, precisam, de alguma forma, ser atendidas. Clima Organizacional reflete, então, uma tendência ou inclinação a respeito de até que ponto as necessidades da empresa e das pessoas que dela fazem parte estariam efetivamente sendo atendidas. 
Os determinantes da percepção de clima organizacional, segundo Tamayo et al (1999) podem ser classificados em duas categorias: individuais e organizacionais. Entre os primeiros, podem ser mencionadas as crenças, os valores pessoais e a personalidade. Os determinantes organizacionais mais importantes são: a estrutura organizacional, os processos, os resultados e os valores da organização. Um dos determinantes individuais do clima organizacional e que merece destaque é constituído pelos valores pessoais. Estes influenciam o julgamento e a avaliação que o funcionário faz do seu ambiente de trabalho. O sentimento de bem-estar do indivíduo na organização deriva da obtenção daquelas coisas que são desejadas, valorizadas e esperadas pelo indivíduo.

São quatro os fatores latentes que sustentam os mais importantes valores pessoais relacionados com o trabalho: o desejo de clareza, harmonia e justiça; o desejo de desafios, independência e responsabilidade; o desejo de facilitação do trabalho, suporte e reconhecimento; e o desejo de relacionamento social amigável e caloroso. A abordagem mais recente dos valores enfatiza a existência de dez tipos motivacionais de valores que parecem ser universais e que expressam metas do indivíduo, revelando aquilo que ele considera que é bom e desejável para si e para a sociedade: autodeterminação, realização, estimulação, prazer, poder social, segurança, universalismo, benevolência, conformidade e tradição (TAMAYO et al, 1999).

A comunicação na organização também é vista como um aspecto vital do clima organizacional. O fluxo, a clareza e a precisão da comunicação são elementos fundamentais na estruturação e coordenação dos funcionários em um sistema social complexo como são as organizações.

\subsubsection{Liderança}

$\mathrm{Na}$ conceituação de Limongi-França e Arellano (2002), a liderança é um processo social no qual se estabelecem relações de influência entre pessoas. A liderança teria quatro grandes funções: pôr em funcionamento uma política, conceber uma estratégia, mobilizar equipes e fazer alianças, criando uma cultura de empresa que seja motivadora. Dentro dessa visão, não há como abordar o tema Endomarketing, sem tratar de liderança. 
Deve-se apenas ressaltar a distinção entre liderança e poder. Apesar de ambos constituírem elementos interligados no processo de influenciar pessoas, o poder é a força no direcionamento dos sistemas e das situações sociais através dos recursos organizacionais, e a liderança possui ou exerce um ou mais tipos de poder. (LIMONGI-FRANÇA e ARELLANO, 2002).

A partir de 1964, Hollander (1978), considerando a importância da motivação do seguidor, propõe a teoria das trocas, destacando que um importante fator na eficácia da liderança é o equilíbrio que deve haver entre as expectativas de um subordinado e as respostas comportamentais oferecidas pelo seu líder. Sugere que a aceitação de um líder será tanto maior quanto mais ele for considerado como agente facilitador dos objetivos realmente almejados pelos subordinados (HOLLANDER,1978). Yukl (1989, p.27) afirma, ao caracterizar o trabalho de Hollander, que "a forma mais fundamental de interação social reside na troca de benefícios e favores, o que leva a atração mútua à medida que se repetem ao longo do tempo". Troca social inclui não apenas benefícios materiais, mas ainda benefícios psicológicos, como expressões de aprovação, respeito, estima e afeição.

Em uma abordagem mais atual, Rowe (2002) apresenta o conceito de liderança estratégica, definida como a habilidade de influenciar pessoas a tomar, de forma voluntária e rotineira, decisões que aumentem a viabilidade em longo prazo da organização, ao mesmo tempo em que mantêm a estabilidade financeira em curto prazo. O diferencial desse enfoque é a preocupação com a criação de valor para a empresa, por meio de decisões que maximizam o retorno sobre o investimento.

Como podemos observar nas diversas abordagens sobre liderança, o assunto tem uma forte correlação com o Endomarketing, na forma que o líder tem que vir a frente em um programa voltado ao atendimento das expectativas e necessidades de seus liderados.

Kotter e Heskett (1994, p. 104) enfatizam a importância e a necessidade da figura do líder em processos de mudança cultural em empresas. Na abordagem desses autores, o líder "precisa criar e comunicar com eficiência a percepção da necessidade de mudança, mesmo quando a maioria acredita que está tudo bem".

\subsubsection{O papel do gerente na perspectiva do endomarketing}


$\mathrm{Na}$ abordagem do Endomarketing, o gerente passa a ter um novo papel junto às organizações, que deve assumir com eficácia dentro de uma estrutura solidária, baseada na delegação do poder e na iniciativa. As empresas precisam se convencer de que, devido o gerente estar entre a cúpula e a base, ele será auxiliado por uma cultura organizacional que assegure a presença de valores compartilhados tanto pela cúpula quanto pela base (BEKIN, 1995).

Ainda segundo Bekin, esses novos gestores têm como sua prioridade centrar o serviço no cliente. Absorver e compreender o que ocorre entre o cliente, o gerente e a equipe comandada por este gerente. A empresa deve apoiá-lo integralmente para que possa assumir seu novo papel na liderança, fornecendo-lhe todos os recursos necessários. A melhor imagem para esse tipo de liderança que irá exercer é a de coach, treinador em português, organiza uma equipe para trabalhar solidariamente, criando as condições para que todo o grupo esteja entrosado para o trabalho coletivo, isto é, para o jogo. Ele orienta a equipe com instruções, corrigindo posições, incentivando o time, treinando jogadas, dando a liberdade de ação para que tenham iniciativa e organizando a melhor tática possível para obter um resultado positivo. O coach constrói com a equipe uma relação próxima, baseada no diálogo, dirige a equipe sem assumir uma posição impessoal, ao contrário, ele também faz parte da equipe, está comprometido e se identifica com ela e seus resultados.

\section{MÉTOdOS E TÉCNICAS DE PESQUISA}

Para Cervo e Bervian (1996), a pesquisa é uma atividade voltada para a solução de problemas, através do emprego de processos científicos. Havendo por parte do ser humano níveis diferentes de aprofundamento e enfoques específicos, conforme o objeto do estudo é natural a existência de diversos tipos de pesquisa, que possuem além do núcleo comum de procedimentos, suas peculiaridades próprias.

A pesquisa bibliográfica tem por finalidade conhecer as diferentes formas de contribuição científica que se realizaram sobre determinado assunto ou fenômeno (OLIVEIRA, 2001). Para Cervo e Bervian (1996, p.48) ela é um "meio de formação por excelência e como resumo de assunto constitui geralmente o primeiro passo de qualquer pesquisa científica”. 
A pesquisa bibliográfica ou de fontes secundárias engloba toda a bibliografia já tornada pública em relação ao tema de estudo, desde publicações avulsas, boletins, jornais, livros, pesquisas recentes, monografias, teses etc., e tem por objetivo permitir ao cientista o reforço paralelo na análise de suas pesquisas ou manipulação de suas informações (LAKATOS; MARCONI, 1991).

A pesquisa descritiva, segundo Cervo e Bervian (1996), observa, registra, analisa e correlaciona fatos ou fenômenos (variáveis) sem manipulá-los. Desenvolve-se, principalmente, nas Ciências Humanas e Sociais, abordando aqueles dados e problemas que merecem ser estudados e cujo registro não consta de documentos.

Segundo Koche (1997), a pesquisa descritiva constata e avalia as relações à medida que essas variáveis se manifestam espontaneamente em fatos, situações e nas condições que já existem. "Na pesquisa descritiva não há manipulação a priori das variáveis (p.124).

A pesquisa descritiva pode assumir diversas formas, entre as quais: estudo exploratório, que define objetivos e busca maiores informações sobre determinado assunto de estudo, realizando descrições precisas da situação e quer descobrir as relações existentes entre os elementos componentes da mesma; estudo descritivo, que é o estudo e descrição das características, propriedades ou relações existentes na comunidade, grupo ou realidade pesquisada; pesquisas de opinião, onde se procura saber atitudes, pontos de vista e preferências que as pessoas têm a respeito de algum assunto; pesquisa documental, através da investigação de documentos, a fim de se descrever e comparar usos e costumes, tendências e outras características (CERVO e BERVIAN, 1996).

Cervo e Bervian (1996), afirma que a pesquisa descritiva, em suas diversas formas, trabalha sobre dados ou fatos colhidos da própria realidade, sendo que a coleta de dados é uma das tarefas características da pesquisa descritiva. Nessa operação de coleta de dados são utilizados, como principais instrumentos a observação, a entrevista, o questionário e o formulário. $O$ estudo de caso é outra forma de pesquisa descritiva.

Este projeto de pesquisa se caracteriza como um estudo de caso, que é definido por Yin (1990) como aquele que examina um fenômeno em seu ambiente natural, dentro de um contexto real. No estudo de caso, as fronteiras entre o fenômeno e o 
contexto não são claramente definidas, devendo ser usadas várias fontes de evidência.

Gil (1988) aponta que o estudo de caso é caracterizado por ser de grande flexibilidade, permitindo que haja a possibilidade de explorar as diversas nuanças de cada tema em particular, com roteiro flexível.

Por sua flexibilidade, o estudo de caso, segundo Doni (1998), é recomendável nas fases iniciais de uma investigação sobre temas complexos, para a construção de hipóteses, reformulação de problemas ou revisão de processos já existentes. Também se aplica com pertinência nas situações em que o objeto de estudo já é suficientemente conhecido a ponto de ser enquadrado em determinado tipo ideal.

$\mathrm{Na}$ abordagem de Doni (1998), o estudo de caso apresenta uma série de vantagens: o estimulo a novas descobertas - em virtude da flexibilidade, a ênfase na totalidade - foco na multiplicidade e dimensões de um problema como um todo e a simplicidade de procedimentos de coleta e análise de dados, quando comparados com os exigidos por outros tipos de metodologias.

Por outro lado, um estudo de caso também apresenta limitações e a mais saliente é a dificuldade de generalização dos resultados obtidos. Pode ocorrer, ainda, que a unidade escolhida para investigação seja bastante anormal em relação às muitas de sua espécie. Este fato pode exigir do pesquisador nível de capacitação mais elevado que o requerido para outros tipos de delineamento.

Outra abordagem quanto à utilização de métodos de pesquisa, no estudo de caso, é a classificação em qualitativo e quantitativo. Segundo Richardson (1989, p.38) o primeiro difere do segundo, em princípio, "na medida em que não emprega um instrumental estatístico como base do processo de análise de um problema. Não pretende numerar ou medir unidades ou categorias homogêneas". O quantitativo utiliza métodos oriundos das ciências físicas, da matemática e da estatística. Caracteriza-se pela adoção de métodos dedutivos e busca a objetividade, a validade e a confiabilidade. O qualitativo origina-se na antropologia e utiliza métodos indutivos, objetivando a descoberta, a identificação, a descrição detalhada e aprofundada.

Há autores que não fazem distinção clara entre métodos quantitativos e qualitativos por entender que a pesquisa quantitativa, é também, de certo modo, qualitativa. Goode e Hatt (1979) entendem que não há, na realidade, separação entre os métodos, qualitativo e quantitativo, e afirmam que a pesquisa moderna deve 
rejeitar como uma falsa dicotomia a separação entre estudos qualitativos e quantitativos, ou entre ponto de vista estatístico e não estatístico. Além disso, não importa quão precisas sejam as medidas, o que é medido continua a ser uma qualidade.

Richardson (1989), também afirma que é possível se reconhecer que a forma como se pretende analisar um problema é que demandará uma metodologia qualitativa ou quantitativa. Para ele, a abordagem qualitativa de um problema é uma opção para entender a natureza de um fenômeno social, e pode estar presente até mesmo nas informações colhidas por estudos essencialmente quantitativos, não obstante seu caráter qualitativo, quando são transformadas em dados quantificáveis, na tentativa de assegurar a exatidão no plano dos resultados.

\subsection{Tipo e descrição geral da pesquisa}

O projeto constitui-se de uma pesquisa descritiva, utilizando as formas de pesquisas quantitativa, documental e estudo de caso, abordando o tema endomarketing dentro da agência de um Banco público localizada na cidade de Paraíso do Tocantins, com intuito de avaliar a efetividade das ferramentas e ações de endomarketing utilizadas para fomentar a motivação, à cultura de treinamento e a comunicação com seus funcionários.

É importante ressaltar que esta pesquisa será realizada de forma a abranger apenas os aspectos voltados às ações e ferramentas de endomarketing do Banco público, não havendo comparativos com de outras instituições do mesmo ramo.

Foi realizada, também, uma pesquisa, através de levantamento bibliográfico sobre 0 assunto central e alguns assuntos correlatos, envolvendo Marketing, Endomarketing e Recursos Humanos. Além disso, procurou-se, dentro do possível, o direcionamento para o mercado bancário, utilizando-se livros, artigos diversos, dentre outros.

Para o alcance dos objetivos deste estudo será realizado uma pesquisa com questionário misto e composto com questões abertas e fechadas que abrangeram os sub-temas: comunicação interna, motivação, treinamento, Clima organizacional e Liderança. 
Esta parte do trabalho seguirá os seguintes passos:

1. Elaboração de roteiros de entrevista com base em aspectos específicos e gerais da Instituição.

2. Transcrição dos dados das entrevistas.

3. Interpretação dos dados transcritos e mensuração do índice de efetividade do programa de endomarketing da instituição financeira.

\subsection{Caracterização da organização, setor ou área do objeto de estudo}

O banco público cuja agência será objeto de análise pelo projeto de pesquisa é o maior banco público do Brasil e da América Latina, possui hoje mais de 109 mil funcionários, mais de 5 mil agências, mais de 50 mil caixas eletrônicos e mais de 40 pontos de atendimento no exterior.

No ano de 2010 lucrou 11,7 bilhões de reais, sendo o segundo maior faturamento entre os bancos no Brasil, perdendo somente para o Itaú Unibanco, possui uma carteira de 52,7 milhões de clientes, administrando 306,2 bilhões em recursos de terceiros.

A agência localizada na cidade de Paraíso do Tocantins possui mais de 9 mil clientes e 30 funcionários, sendo deles 7 gerentes de relacionamento, 1 gerente geral e 1 gerente de negócios que assume a administração da agência na ausência do gerente geral. É classificada como uma agência de nível 3, essa classificação varia de acordo com o porte da cidade e o volume de negócios, sendo o nível 5 a de menor volume e nível 1 a de maior.

A cidade de Paraíso do Tocantins, localizado no estado do Tocantins, segundo o IBGE, possui cerca de 44.417 habitantes, o PIB do município em 2010 atingiu mais de 423 milhões de reais. Possui 5 instituições financeiras oficiais que em 2010 movimentaram mais de 167 milhões de reais em operações de crédito. 


\subsection{Participantes do estudo}

A pesquisa será realizada com os 30 funcionários lotados na agência Paraíso do Estado do Tocantins, através de formulário eletrônico que será enviado a 100\% da amostra.

\subsection{Instrumento(s) de pesquisa}

As informações a serem utilizadas neste estudo serão obtidas mediante:

a) Pesquisa documental: Consulta a livros, artigos, documentos institucionais, relatórios fornecidos pela instituição financeira e intranet.

b) Aplicação de questionário: Para essa análise foi elaborado questionário compostos por questões abertas e fechadas, sendo as oito primeiras para identificação do perfil dos analisados, encaminhadas através de formulário eletrônico para todos os funcionários lotados na agência anteriormente caracterizada.

\subsection{Procedimentos de coleta e de análise de dados}

A coleta de dados será realizada mediante os seguintes procedimentos: Leitura e análise de documentos internos da Organização.

Em seguida, mediante a aplicação de pesquisa de opinião, com questionário quantitativo, com a necessária delimitação do universo e da amostra da pesquisa anteriormente descrita.

A pesquisa para avaliar a efetividade das ferramentas de endomarketing utilizadas para fomentar a motivação, à cultura de treinamento e a comunicação para com seus funcionários lotados na agência, será remetida a todos os funcionários um link do questionário via email, não se identificando os respondentes.

$\mathrm{Na}$ pesquisa foi utilizada a média aritmética simples das respostas para apuração dos resultados em cada questão. Esta nota média foi convertida em percentual utilizando-se uma regra de três simples, onde o total de formulários 
respondidos corresponde a 100\%. Para apuração do percentual de alternativas será calculado conforme fórmula abaixo:

\begin{tabular}{|c|c|c|c|c|c|c|}
\hline $\begin{array}{c}\text { Percentual } \\
\text { da alternativa }\end{array}$ & $=$ & $\begin{array}{c}\text { Quantidade de marcações } \\
\text { por alternativa }\end{array}$ & $X$ & 100 & 1 & $\begin{array}{c}\text { Quantidade de } \\
\text { formulários } \\
\text { respondidos }\end{array}$ \\
\hline
\end{tabular}

Tabela 1 - Fórmula de apuração dos resultados

Sendo que o somatório dos percentuais apresentados por alternativa não podem ultrapassar o valor de 100\% (cem por cento).

Todos os 30 funcionários da agência responderam o questionário. 


\section{RESULTADOS}

Neste capítulo são apresentados os resultados da pesquisa para avaliar a efetividade da política de endomarketing na agência, agrupada em cinco horizontes (comunicação interna, motivação, treinamento, clima organizacional e Liderança), além da análise crítica das entrevistas e do exame da instituição financeira através de documentos, organogramas e procedimentos operacionais.

\subsection{DADOS DA ORGANIZAÇÃO EM ESTUDO}

\subsubsection{Dados Sociais}

A Agência Paraíso, subordinada a Superintendência do Tocantins, cumpre seu papel na área de varejo do conglomerado financeiro.

A força de trabalho da Agência Paraíso é composta por 30 funcionários, conforme descritos abaixo:

\begin{tabular}{lc}
\multicolumn{1}{c}{ FUNÇÃO } & QUANTIDADE \\
GERENTE GERAL & 1 \\
GERENTE DE NEGÓCIOS & 1 \\
GERENTE DE RELACIONAMENTO & 5 \\
GERENTE DE SERVIÇOS & 3 \\
ASSISTENTE DE NEGÓCIOS & 4 \\
SUPERVISOR DE ATENDIMENTO & 1 \\
CAIXA & 7 \\
ESCRITURÁRIO & 8
\end{tabular}

Dos funcionários $70 \%$ são homens e $30 \%$ mulheres, $46,67 \%$ dos funcionários possuem mais de 40 anos e $53,33 \%$ possuem até 30 anos de idade. Com relação a tempo de trabalho na instituição $53,33 \%$ dos funcionários tem até 5 anos de banco, $13,33 \%$ tem de 6 a 10 anos e 33,33\% dos funcionários tem mais de 11 anos. 
Ao questionar os funcionários sobre o tempo que exerce a mesma função/comissão, $83,33 \%$ dos funcionários tem até 5 anos na mesma função e somente $10 \%$ tem mais de 11 anos na mesma função.

O perfil do nível de escolaridade dos funcionários da dependência apresenta-se assim distribuído:

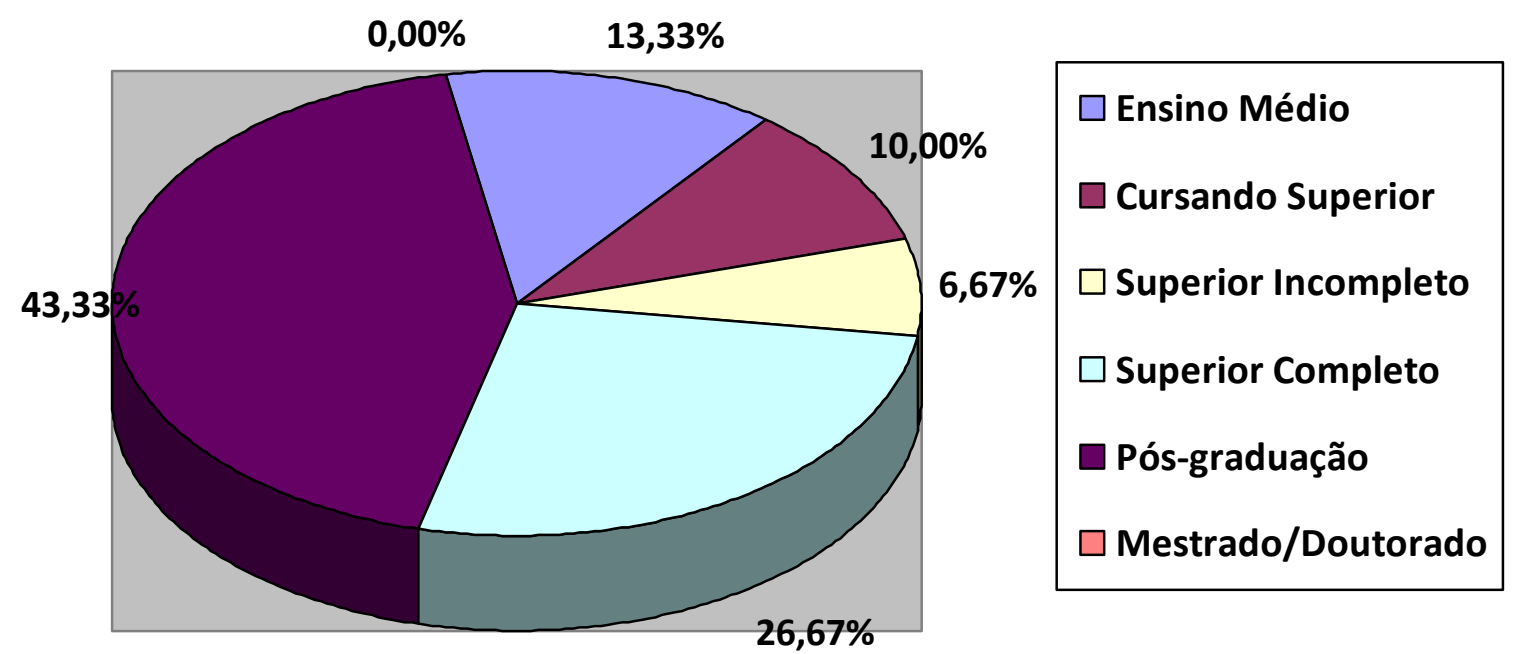

Gráfico 1 - Nível de escolaridade dos funcionários

\subsubsection{Comunicação Interna}

Para avaliar a comunicação interna, foram elaboradas 5 (cinco) questões, sendo a quinta questão uma avaliação sobre as ferramentas disponibilizadas pela instituição para facilitar a comunicação.

Ao questionar os funcionários sobre a freqüência com que lê as notícias disponibilizadas pela instituição financeira, verifiquei que 63,33\% lêem diariamente essas notícias, às vezes até mais de uma vez por dia e 36,67\% afirmaram que lêem em dias alternados, não mantendo uma freqüência exata.

A instituição financeira dispõe a seus funcionários vários canais de comunicação, e eles são: 
Agência de Notícias - é um canal disponibilizado para divulgar fatos e acontecimentos da instituição financeira e do mercado, quando este afeta diretamente os negócios da empresa. Essas notícias têm caráter regulatório quando se trata de mudança em procedimentos, instruções e normas de regulação externa, de caráter social quando se trata de campanha de marketing social, como programas de voluntariado, natal solidário, incentivo a qualidade de vida no trabalho e etc., de caráter institucional e mercado quando se trata de estratégias de atuação, comissionamento de administradores, seleções internas, mudanças no mercado, alteração em taxas de juros, etc. Ao questionar os funcionários sobre o grau de satisfação, $90 \%$ se manifestaram satisfeitos com as funcionalidades da ferramenta, $6,67 \%$ se manifestaram pouco satisfeitos e 3,33\% muito insatisfeitos. Os funcionários que se manifestaram pouco satisfeitos e muito insatisfeitos argumentaram que a nota se deu devido à dificuldade de encontrar matérias de seu interesse, pois a disponibilização das matérias somente se divide por nacionais e estaduais, não existindo a opção de filtrar por tema. Com relação à compreensão das notícias veiculadas, $93,33 \%$ dos funcionários afirmaram que a linguagem apresentada é de fácil entendimento.

Email Coorporativo - é um canal de comunicação muito utilizado para delegação de tarefas e divulgação de informações institucionais, como mensagens do presidente e informativos da Gerência de Gestão de Pessoas (GEPES), para comunicação externa é um elo com os clientes e fornecedores. Como o email coorporativo é muito recente na instituição que se utilizava de um programa de emissão de mensagens coorporativo (CORREIO), questionamos os funcionários sobre a freqüência com que acessam o seu email, e somente $23,33 \%$ afirmaram acessar diariamente, 53,33\% afirmaram acessar em dias alternados, sem uma seqüência lógica de alternância, 16,67\% afirmaram que acessam às vezes e 6,67\% afirmaram que nunca acessaram o email ou se quer sabiam da sua existência para todos. A argumentação apresentada pelos funcionários que afirmaram acessar "às vezes" foi que a relevância das informações repassadas via email pouco influencia as suas atividades de trabalho, os que afirmaram "nunca" ter acessado o email informou que desconhecia a ferramenta disponibilizada pela instituição.

Aplicativo Responde - é uma ferramenta para soluções de dúvidas em relação as instrução normativas e/ou procedimentos operacionais. Quando a leitura das instruções normativas não está clara e resta uma dúvida sobre o procedimento a ser 
tomado, existe a possibilidade de se utilizar dessa ferramenta para envio da dúvida e posteriormente receber a solução do questionamento. Abaixo temos um gráfico que demonstra a satisfação dos funcionários com relação à ferramenta:

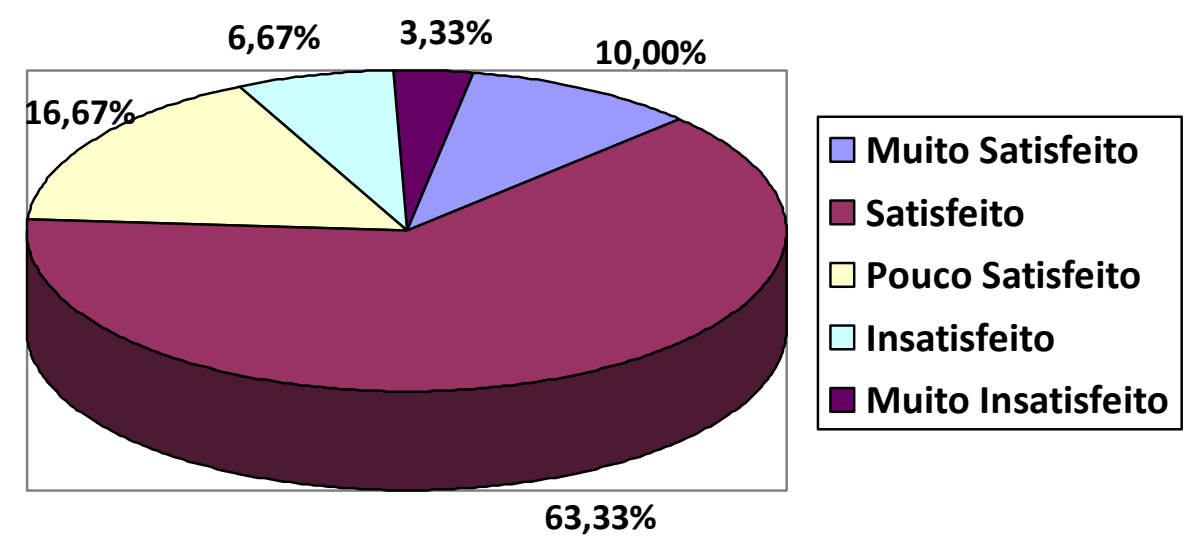

\section{Gráfico 2 - Satisfação com Aplicativo Responde}

Os funcionários que se manifestaram como pouco satisfeitos, insatisfeitos e muito insatisfeitos, argumentaram que a nota foi atribuída devido à falta de agilidade na solução da dúvida, ou seja, o canal existe, porém o tempo de espera para resposta é muito longo e pode comprometer o prazo de conclusão do serviço.

Instruções Normativas - é o livro de receitas, contém todas as normativas e procedimentos operacionais da instituição, desde o código de ética até as normas de regulação externa. Recentemente sofreu reformulações, mudando nome e plataforma operacional, antes se chamava LIC - Livro de instruções Codificadas e passou a se chamar IN - Instruções Normativas, era disponibilizado em plataforma MS-DOS, com estética ultrapassada e sem opções que facilitassem a navegação, passou a ser disponibilizado em plataforma web, de fácil utilização e com navegação amigável e intuitiva. Com relação à satisfação dos funcionários com a atual ferramenta, $86,67 \%$ afirmaram estar satisfeitos ou muito satisfeitos com a IN, $10 \%$ alegaram estar pouco satisfeitos devido à instabilidade que a ferramenta ainda apresenta, e somente 3,33\% alegaram estar insatisfeitos ou muito insatisfeitos com a plataforma, pois afirmaram que já estavam acostumados com o modelo anterior e que ainda acham muito confusa a nova ferramenta.

Centrais de Atendimento - são divididas em externas (clientes externos) e internas (clientes internos), vou tratar somente das Centrais de Atendimento Interno, 
elas existem para sanar dúvidas levantadas pelos funcionários de forma ágio e imediata e auxiliar na venda e contratação de produtos e serviços. Com relação à satisfação com a ferramenta, identifiquei que $60 \%$ dos funcionários estão satisfeitos ou muito satisfeitos e que $40 \%$ estão pouco satisfeitos, insatisfeitos ou muito insatisfeitos, a principal argumentação é a falta agilidade no atendimento, a demora na espera por um atendente disponível e a falta de preparo por parte dos atendentes.

Mensagens Instantâneas - é uma ferramenta nova, criada este ano, veio substituir o antigo CORREIO PESSOAL, aplicativo para enviar mensagens informais entre os funcionários da instituição, o aplicativo mensagens instantâneas funciona como um MSN, onde o colaborador pode trocar mensagens em tempo real com os colegas que estiverem cadastrados no seu aplicativo. Com relação à satisfação dos funcionários, $86,67 \%$ afirmaram estar satisfeitos ou muito satisfeitos com a ferramenta, 10\% afirmaram estar pouco satisfeitos e 3,33\% estão insatisfeitos devido à instabilidade de conexão que ainda apresenta o aplicativo.

TV institucional - meio de comunicação utilizado para anúncios institucionais e mudanças na estratégia do Banco, utilizado também para cursos e treinamentos. É um meio de comunicação pouco aproveitado, principalmente sobre a ótica de treinamento onde ela se configura como ferramenta estratégica. Com relação à satisfação dos funcionários, 66,67\% estão satisfeitos ou muito satisfeitos com o meio de comunicação, 16,67\% afirmaram estar pouco satisfeitos e 16,67\% afirmaram estar insatisfeitos ou muitos insatisfeitos, ao serem questionados sobre o motivo de estarem pouco satisfeitos, insatisfeitos ou muito insatisfeitos, afirmaram que a avaliação é devido ao sub-aproveitamento do meio de comunicação, da falta de aplicabilidade do que é divulgado ou mesmo duplicidade da informação (informação já veiculada em outro canal). A TV institucional esta perdendo espaço para mídias de acesso mais facilitado como a intranet e a veiculação de vídeos institucionais através da plataforma web, antes o colaborador tinha de aguardar na sala de reuniões o horário para assistir um programa institucional, hoje o colaborador entra na intranet e assisti ao vídeo a qualquer hora.

Revista Institucional - é de distribuição mensal, via mídia impressa e digital (o colaborador escolhe a mídia que deseja receber), são veiculados notícias e informativos sobre qualidade e vida no trabalho, equidade de gênero, dicas de saúde, benefícios que os funcionários dispõem, iniciativas sociais e ambientais por 
parte de funcionários ou pela instituição. Com relação à satisfação com o meio de comunicação, $83,33 \%$ dos funcionários estão satisfeitos ou muito satisfeitos e $16,67 \%$ manifestaram-se pouco satisfeitos com a revista devido à superficialidade das matérias veiculadas e pouca interação com o dia a dia do colaborador.

Ouvidoria Interna - é um canal de comunicação criado para acolher denúncias, reclamações, e elogios dos funcionários, além de buscar a melhoria contínua dos processos, programas e políticas da área de Gestão de Pessoas e Responsabilidade Socioambiental. Ao questionar os funcionários sobre a satisfação, $83,33 \%$ afirmaram estar satisfeitos ou muito satisfeitos com o meio de comunicação, $16,67 \%$ afirmaram estar pouco satisfeitos devido à demora no tratamento das denúncias recebidas pelo meio de comunicação.

Ecoa - sua sigla significa "Equipe de Comunicação e Auto-desenvolvimento, promovida pelo banco público para ser o elo entre a direção da agência e os demais funcionários, é composto por 4 pessoas em agências de maior porte e por 2 pessoas em agências de pequeno porte, cuida também das atividade sócio-ambientais promovidas pelas agências. Com relação a satisfação dos funcionários, 96,67\% dos funcionários estão satisfeitos ou muito satisfeitos com a Ecoa e somente 3,33\% manifestaram-se pouco satisfeitos.

$\mathrm{Na}$ agência foi verificado via questionário que $93,33 \%$ dos funcionários detêm conhecimento bem definidos das metas, objetivos e estratégias do Banco, e somente $6,67 \%$ afirmaram não deter esse conhecimento, pois devido ao pouco tempo de trabalho, ainda não entendeu o funcionamento da organização e a distribuição das tarefas na agência.

\subsubsection{Motivação}

Foi questionado o grau de motivação dos funcionários com relação a diversos aspectos, como: oportunidades de ascensão e desenvolvimento profissional, ações de formação profissional, divisão das atividades na agência e a relação cargo/comissão exercida e remuneração e benefícios recebidos. 


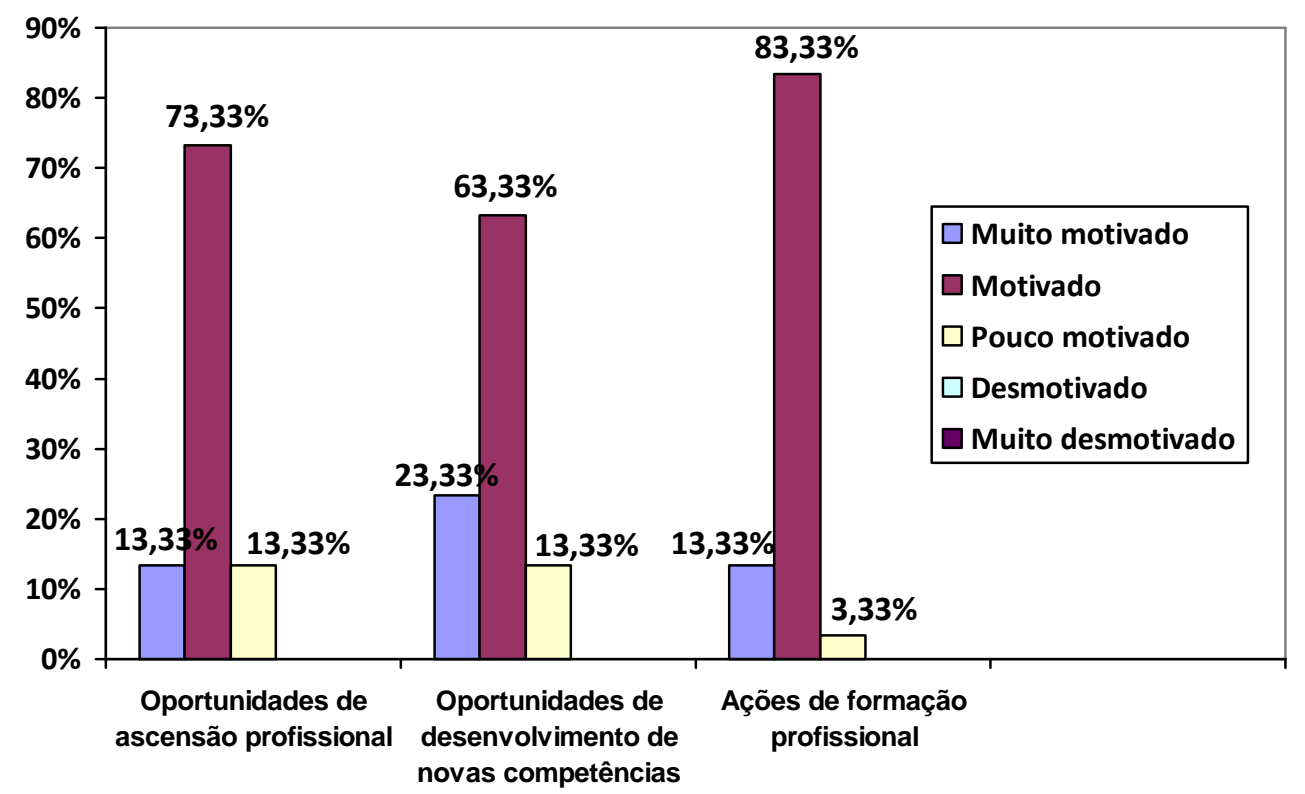

Gráfico 3 - Nível de Motivação dos funcionários I

Podemos verificar no gráfico acima que ao questionar os colabores sobre as oportunidades de ascensão e de desenvolvimento de novas competências disponíveis na instituição financeira, 86,67\% afirmaram estar motivados ou muito motivados e 13,33\% afirmaram estar pouco motivados. Com relação às ações de formação profissional desenvolvidas na instituição, 96,67\% dos funcionários afirmaram estar motivados ou muito motivados e somente $3,33 \%$ afirmaram estar pouco motivados.

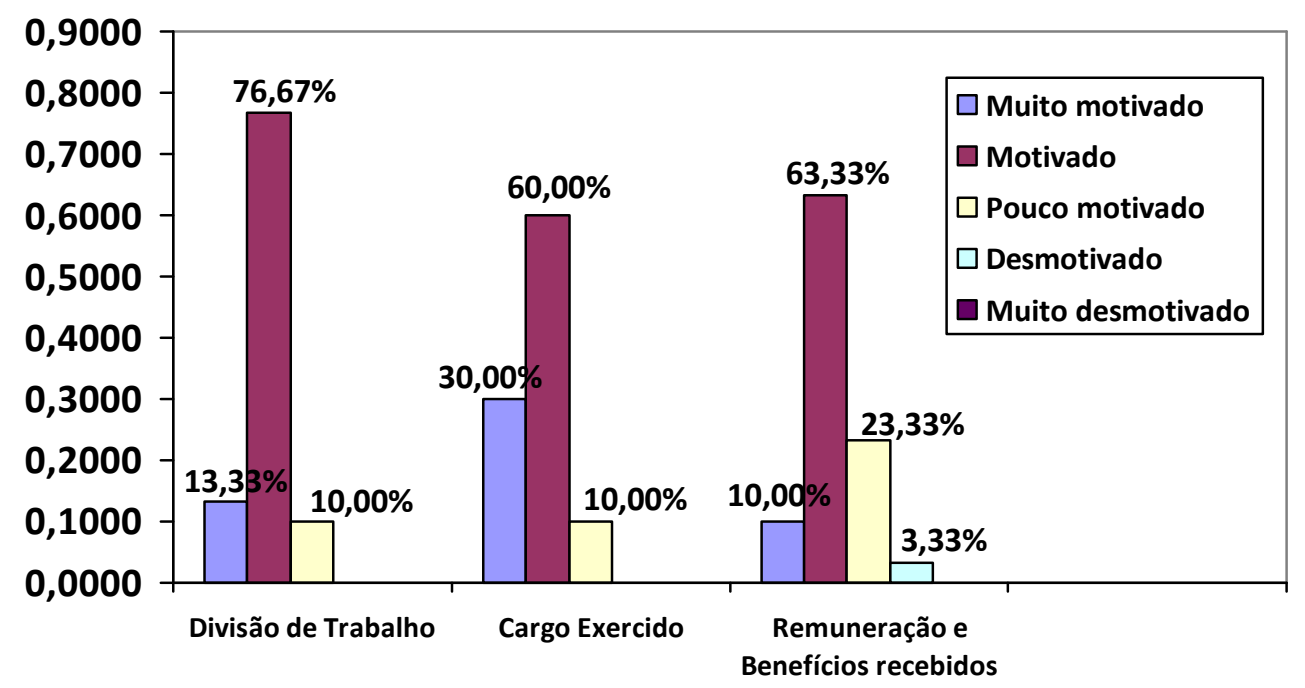

Gráfico 4 - Nível de Motivação dos funcionários II

No gráfico 4 (quatro), podemos verificar o grau de motivação dos funcionários relativo a divisão de trabalho, cargo exercido e remuneração e benefícios recebidos. 
90\% dos funcionários afirmaram estar motivados ou muito motivados com relação à divisão de trabalho e o cargo exercido e 10\% manifestaram estar pouco motivados, já quando questionados sobre a relação cargo exercido e atividade desenvolvida versus remuneração recebida, $73,33 \%$ dos funcionários se manifestaram motivados ou muito motivados, $23,33 \%$ se manifestaram pouco motivados e 3,33\% afirmaram estar desmotivados, que leva a concluir que parte da agência está insatisfeita com o valor e benefícios que recebe para exercer a sua função, mas este indicador não está influenciando negativamente o nível de motivação da equipe, uma vez que ao questioná-los sobre o seu grau de motivação pessoal 96,67\% afirmaram estar motivados ou muito motivados e somente 3,33\% afirmaram estar pouco motivados.

Ao considerar o grau de motivação pessoal e o grau de motivação com relação aos objetivos e metas definidos para a agência, o percentual se repetiu com $96,67 \%$ afirmando estarem motivados ou muito motivados e 3,33\% afirmando estar pouco motivados.

\subsubsection{Treinamento}

O questionário na temática de treinamento teve como foco o Programa de Educação Empresarial, quem tem como função a atualização e aperfeiçoamento das habilidades técnicas e negociais dos funcionários.

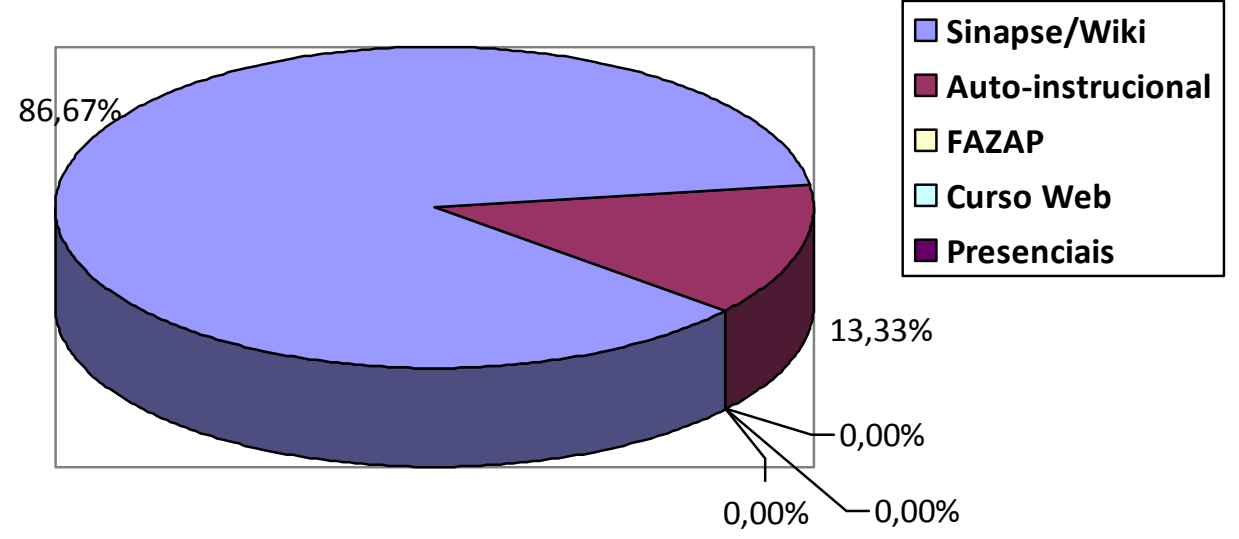

Gráfico 5 - Treinamentos mais utilizados

O gráfico acima mostra que $13,33 \%$ dos funcionários afirmaram utilizar com mais freqüência os cursos auto-instrucionais para aprimorar seus conhecimentos e 86,67\% utilizam mais o ambiente sinapse, desenvolvido pela Diretoria de Gestão de 
Pessoas como uma modalidade de treinamento em produtos e serviços baseada em ambiente wiki, que é uma forma autônoma e colaborativa de produção de conteúdo. O ambiente propicia um processo de enriquecimento permanente dessas informações por meio da participação dos funcionários.

Em seguida, os funcionários foram questionados sobre qual modalidade de treinamento ele acredita ter melhor aproveitamento de aprendizado.

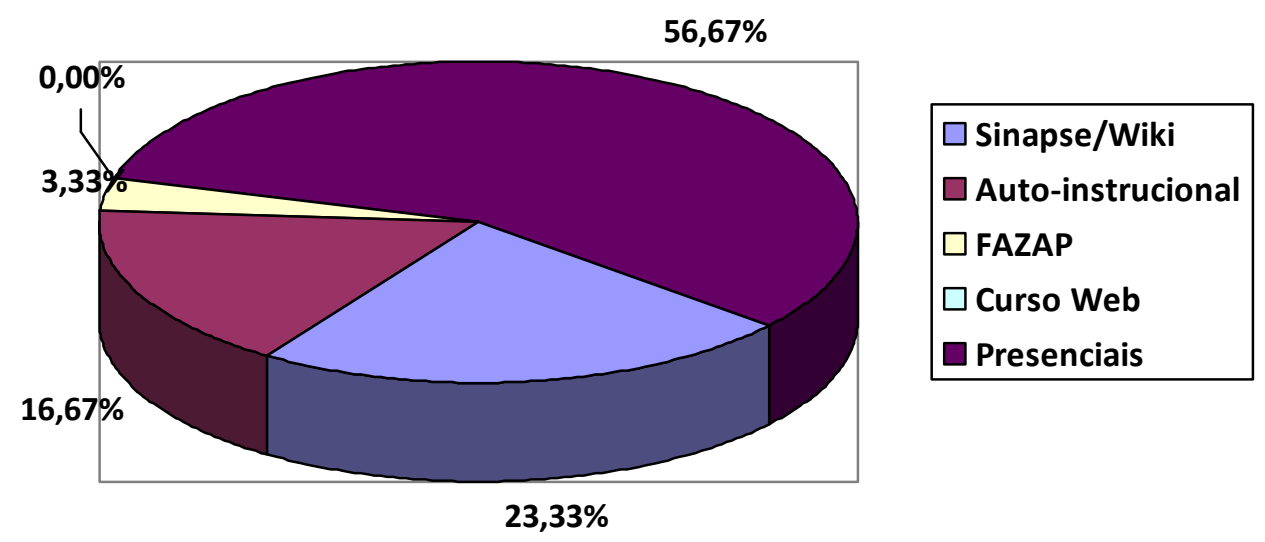

Gráfico 6 - Treinamentos com melhor aproveitamento

$O$ treinamento auto-instrucional e o treinamento Sinapse foram apontados respectivamente por $16,67 \%$ e $23,33 \%$ dos funcionários como treinamento de melhor aproveitamento. Já o curso presencial foi apontado por $56,67 \%$ dos funcionários como o treinamento de melhor aproveitamento, e somente 3,33\% afirmaram que o FAZAP, modalidade de curso em serviço (fazendo e aprendendo), é o de melhor aproveitamento. Foi questionado também quando foi a última vez que o colaborador participou de um treinamento presencial, e o espaço temporal obtido foi bem variado, onde $70 \%$ estiveram em um treinamento presencial nos últimos 7 meses e $30 \%$ não participam de um curso presencial a mais de 7 meses. 


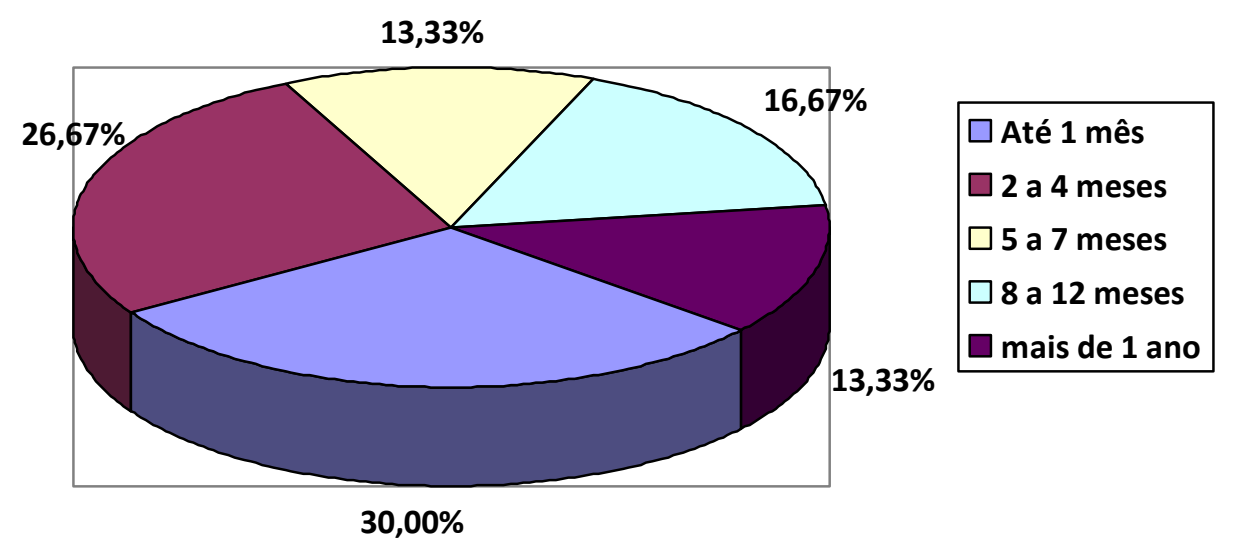

Gráfico 7 - Período de treinamento presencial

Seguindo a análise foi questionado quanto tempo eles se dedicavam a cursos/treinamentos por semana, e chegamos ao seguinte resultado: $33,33 \%$ afirmaram dedicar 1 hora por semana, 43,33\% afirmaram dedicar de 2 a 3 horas por semana, 16,67\% afirmaram dedicar de 4 a 5 horas por semana e somente $6,67 \%$ afirmaram dedicar mais de 10 horas por semana. Em conseguinte, foi questionado se existe incentivo por parte da administração da agência para a cultura de treinamento, e $100 \%$ dos funcionários afirmaram ter esse incentivo por parte da administração da agência.

Então, foi questionado se o colaborador se sente treinado para exercer a sua função junto à instituição financeira, 76,67\% afirmaram estar treinados e 23,33\% afirmaram não estar treinado o suficiente para exercer a sua função.

\subsubsection{Cultura/Clima Organizacional e Liderança}

Observou-se no resultado do questionário que $100 \%$ dos funcionários afirmaram ter a liberdade de expressar opiniões diferentes dos seus chefes diretos no que diz respeito ao andamento das atividades promovidas no setor/agência, que sua equipe de trabalho é motivada e sempre busca objetivos comuns, procuram participar das decisões que afetam o trabalho no seu setor/agência, sentem que seu trabalho é estimulante e motivador, que a comunicação verbal é facilmente compreendida no seu setor/agência e que o relacionamento no ambiente de trabalho é amigável. 
Em relação à parcela de poder de decisão e autonomia inerente ao trabalho, $93,33 \%$ afirmaram ser suficientes para desenvolver as atividades sob sua responsabilidade, 6,67\% afirmaram não ser suficientes.

Em relação ao reconhecimento, 93,33\% dos funcionários afirmaram sentir que têm seu potencial devidamente reconhecido, 6,67\% afirmaram que não se sente reconhecido.

Foi questionado aos funcionários se eles têm tranqüilidade para executar suas tarefas dentro de um ritmo normal, com distribuição equitativa de carga de trabalho entre os colegas, $70 \%$ afirmaram que detém essa tranqüilidade e $30 \%$ afirmaram que não.

Em relação às metas e objetivos da agência, 93,33\% dos funcionários afirmaram ter uma boa visão sobre as metas e objetivos da sua agência, 6,67\% afirmaram não ter essa visão. Foi questionado aos funcionários se eles têm a certeza daquilo que esperam deles e onde podem chegar na instituição, 86,67\% afirmaram que têm essa certeza, já 13,33\% afirmaram que não há possuem.

Com relação ao superior imediato, $90 \%$ afirmaram que os seus superiores imediatos aceitam facilmente as suas sugestões e 10\% afirmaram que não. 100\% dos funcionários afirmaram que seus superiores imediatos se manifestam positivamente quando demonstram um desempenho acima do esperado e que seus superiores imediatos se preocupam em manter suas equipes informadas sobre as mudanças que possam afetar o trabalho no setor/agência.

Com relação às mudanças, foi questionado aos funcionários se as mudanças em procedimentos, produtos ou serviços são comunicadas e explicadas com antecedência, 76,67\% afirmaram que "sim" e 23,33\% afirmaram que não, sobre o argumento que sempre é avisado em cima da hora sem muitas explicações e a compreensão vem com o desenvolvimento das atividades. Foi questionado também se as ordens vêm acompanhadas de todas as informações necessárias para a execução do trabalho, $80 \%$ afirmaram que "sim", sempre vêm acompanhadas e $20 \%$ afirmaram que não, nem sempre.

Com relação ao relacionamento na ambiente de trabalho, $80 \%$ dos funcionários afirmaram não existir competitividade exagerada no ambiente de trabalho, $20 \%$ afirmaram que existe às vezes competitividade exagerada. 


\section{CONCLUSÕES E RECOMENDAÇÕES}

Com base nos resultados obtidos pela pesquisa, conclui-se que as ações e ferramentas de endomarketing utilizadas na agência analisada são efetivas. Essa afirmação é baseada nos resultados obtidos através do formulário pesquisa que analisou os seguintes indicadores: Comunicação Interna, Motivação, Treinamento, Clima Organizacional e Liderança.

No indicador Comunicação interna ficou evidenciado que o Banco público disponibiliza as suas agências ferramentas que auxiliam na disseminação da informação. Porém, algumas ferramentas precisam ser aprimoradas, como:

O Aplicativo Resolve que apresenta demora na resolução das demandas e que o tempo de resposta às vezes pode comprometer o prazo de conclusão dos serviços, o que é gravíssimo, e precisa ser revisto pelas diretorias do Banco.

A Central de Atendimento Interno, que também devido à demora no atendimento e falta de preparo dos atendentes pode comprometer as vendas e o resultado da agência. Logo, existe a necessidade de avaliar uma forma de filtrar as demandas para não sobrecarregar os atendentes e a necessidade de treiná-los melhor para que $o$ atendimento seja eficiente e eficaz.

No Email Coorporativo, somente $23,33 \%$ dos funcionários afirmaram acessar diariamente, em parte esse resultado é reflexo da transição das mensagens coorporativas do aplicativo CORREIO para o Email Coorporativo, hoje a maioria das mensagens coorporativas ainda são encaminhadas pelo aplicativo CORREIO, porém, há necessidade de se iniciar uma campanha pelo uso do Email Coorporativo dado a importância que ele detém na comunicação interna.

Em relação à TV institucional, com o avanço da intranet e a possibilidade de disponibilizar vídeos com acesso ágil e fácil, além da flexibilidade de tempo para visualização, fez com que esse meio de comunicação entra-se em desuso, porém pode ser reaproveitado pela direção do Banco para a disponibilização de cursos de treinamento telepresenciais.

No indicador Treinamento ficou evidenciado que os cursos na modalidade autoinstrucionais e a distância são os mais utilizados pelos funcionários da agência analisada, porém a maioria dos funcionários afirmaram disponibilizar menos de 3 horas semanais para treinamento, sendo que 33,33\% afirmaram dedicar até 1 hora 
por semana, outro fator interessante é que a maioria dos funcionários afirmaram acreditar que os treinamentos presenciais são os com melhor aproveitamento, isso é devido aos cursos presenciais acontecerem fora da agência, em local diferenciado, onde o funcionário disponibiliza um tempo para se dedicar ao seu aperfeiçoamento, o que não acontece com os treinamentos a distância e auto-instrucionais onde o funcionário estuda na agência em horas vagas sem um local adequado que lhe proporcione tranquilidade para a assimilação do conteúdo. Recomenda-se que a agência organize um local adequado e disponibilize um horário para treinamento dos funcionários, a fim de melhorar a assimilação do conteúdo.

No indicador Motivação, a agência analisada apresentou de modo geral um nível de motivação satisfatório, onde $96,67 \%$ dos funcionários afirmaram estar motivados ou muito motivados com relação a seu trabalho. O resultado não é só reflexo dos incentivos e benefícios disponibilizados pelo Banco, mas é também reflexo, da flexibilidade e acessibilidade apresentada pelos gerentes, que mantém uma boa comunicação com suas equipes, incentivando a auto-gestão através da administração participativa, valorizando as iniciativas e idéias dos membros das equipes. Nesse sentido Brum (1998), afirma que "a valorização e reconhecimento das pessoas tem como cunho o estímulo e motivação das pessoas para o trabalho".

A agência analisada também promove ações próprias de endomarketing como forma de motivar os funcionários e mantê-los comprometidos com as metas e objetivos da agência. Posso citar como exemplo de iniciativas próprias, as campanhas internas de vendas que premia os funcionários com brindes, o lixo nobre que incentiva o uso eficiente do papel e a reciclagem e os rankings de vendas com a valorização dos maiores vendedores no mural da agência.

Com relação aos funcionários serem concursados, Paladini (1990), afirma que "o medo não constitui fator de motivação e que sua eliminação também não a promove, criando-se apenas uma lacuna", logo a estabilidade proporcionada pelo fato dos funcionários entrevistados serem concursados não é fator de motivação e nem de acomodação, pois Paladini (1990) afirma que a abordagem motivacional está vinculada ao conceito de automotivação das pessoas, no qual estas passam a envolverem-se com aquilo que fazem, respondendo por sua ação.

Os resultados apresentados no indicador Clima Organizacional e Liderança, que foram analisados juntos pelo fato da liderança influenciar diretamente o clima organizacional, são reflexos dos resultados obtidos nos demais indicadores. Pois 
para Coda (1997), em administração, Clima Organizacional é o indicador do grau de satisfação dos membros de uma empresa, em relação a diferentes aspectos da cultura ou realidade aparente da organização, tais como: política de recursos humanos, modelo de gestão, missão da empresa, processo de comunicação, valorização profissional e a identificação com a empresa.

Por fim, a qualidade do clima organizacional irá se refletir na qualidade do atendimento prestado pela agência analisada e na qualidade de vida dos funcionários, de modo a promover o crescimento sustentável dos negócios e a retenção dos talentos desenvolvidos na empresa. Daí a importância de se avaliar constantemente o clima organizacional das agências para assim medir a efetividade das ações e ferramentas de endomarketing utilizadas pelo Banco. 


\section{REFERÊNCIAS}

BEKIN, S. F. Conversando sobre endomarketing. São Paulo: Makron Books, 1995.

BRUM, A. M. Endomarketing como estratégia de gestão: encante seu cliente interno. Porto Alegre: L\&PM, 1998.

CARVALHO, A. V. Administração de recursos humanos. São Paulo: Pioneira, 1997.

CASADO, T.; LIMONGI-FRANÇA, A.C.; ARELLANO, E.B. et alii. As pessoas na organização. São Paulo: Editora Gente, 2002.

CERQUEIRA, W. Endomarketing: educação e cultura para a qualidade. Rio de Janeiro: Qualitymark, 1994.

CERVO; A.L; BERVIAN, P.A. Metodologia Científica. São Paulo: Makron Books, 1996.

CHIAVENATO, I. Gestão de Pessoas: O novo papel dos recursos humanos nas organizações. 6ª tiragem. Rio de Janeiro: Campus, 1999.

CODA, Roberto. Psicodinâmica da vida organizacional: motivação e liderança. São Paulo: Atlas, 1997.

CURVELLO, J. J. A. Comunicação interna e cultura organizacional. São Paulo: Scoterci, 2002.

DONI, M.E. Apostila Metodologia do Trabalho Científico. Universidade Federal do Paraná. Curitiba, 1998.

GIL, A. Como elaborar projetos de pesquisa. São Paulo: Atlas, 1988.

GOODE, W. J; HATT, P. K. Métodos em pesquisa social. São Paulo: Cia Editora Nacional, 1979.

HERSEY, P.; BLANCHARD, K. Psicologia para Administradores: A teoria e as técnicas da liderança situacional. São Paulo: EPU, 1982.

HOLLANDER, E.P. Leadership dynamics: a practical guide to effective relationships. Londres: Free, 1978.

INKOTTE, A. L. Endomarketing: elementos para a construção de um marco teórico. 2000. Dissertação de Mestrado. Departamento de Engenharia de Produção e Sistemas. Universidade Federal de Santa Catarina. Florianópolis, SC.

KOCHE, J.C. Fundamentos de metodologia científica. Petrópolis: Vozes, 1997. 
KOTLER, P. Administração de marketing: análise, planejamento e controle. São Paulo: Atlas, 1998.

KOTTER, John; HESKETT, James L. Cultura corporativa e desempenho empresarial. Makron Books Editores: São Paulo, 1994.

LAKATOS, E.M; MARCONI, M.A. Fundamentos de metodologia científica. São Paulo: Atlas, 1991.

LAMBERT, T. Ferramentas da administração: 50 técnicas para resolver os problemas diários da empresa. São Paulo: Saraiva, 1996.

LAS CASAS, A. L. Marketing de Serviços. São Paulo: Atlas, 2000

MARRAS, J. P. Administração de Recursos Humanos: Do Operacional ao Estratégico. 4. ed. São Paulo: Futura, 2001.

MEIRA P. R.; OLIVEIRA R. L. T. O endomarketing. 2004. Disponível em <http://www.endomarketing.com/01.html> Acesso em 24 mai. 2011.

MORGAN, G. Imagens da organização. São Paulo: Atlas, 1996.

OLIVEIRA, S.L. Tratado de metodologia científica. São Paulo: Pioneira Thomson Learning, 2001.

PALADINI, E.P. Controle de Qualidade: uma abordagem abrangente. São Paulo: Atlas, 1990.

PORTAL BANCO DO BRASIL. Sustentabilidade. Disponível em $<$ http://www.bb.com.br/portalbb/page3,8305,8339,0,0,1,6.bb?codigoMenu=3801\&cod igoNoticia=4554\&codigoRet=3814\&bread=5> Acesso em 15 out. 2011.

RICHARDSON, R.J. Pesquisa social: métodos e técnicas. Santos: Atlas, 1989.

ROBBINS, S. Organizational Behavior, NJ-Prentice Hall: 1996;

ROWE, W. Glenn. Liderança estratégica e criação de valor. Revista de Administraçao de Empresas, São Paulo, 42 (1); 7-19, Jan.Mar. 2002.

SCHEIN, E. Organizational culture and leadership. São Francisco: Jossey Bass, 1986.

SOUZA, Carlos. Desenvolvimento e deteriorização organizacional. São Paulo: Atlas, 1978.

TAMAYO, A et al Trabalho, organizações e cultura. São Paulo: Cooperativa de Autores Associados, 1999. 
WERTHER, Willian B. Administração de pessoal e recursos humanos. São Paulo: Makron Books, 1993.

YIN, R. Case Study Ressearch - Design and Methods, Califórnia: Sage Publication, 1990.

YUKL, G.A Leadership in organizations. Englewood Cliffs: Prentice-Hall, 1989. 


\section{ANEXOS}

\section{Formulário de pesquisa}

\section{Dados Sociais}

Qual o seu sexo?

( ) Masculino

Qual a sua idade?

( ) 18 a 25 anos

) 26 a 30 anos

) 31 a 40 anos

Qual seu estado civil?

( ) Solteiro

Qual seu grau de escolaridade?

( ) Ensino Médio

( ) Cursando Superior

( ) Superior Incompleto

Há quanto tempo trabalha no Banco?

( ) até 1 ano

( ) 2 a 5 anos

) 6 a 10 anos

Qual seu atual cargo?

( ) Escriturário

( ) Assistente de Negócios

( ) Gerente de Relacionamento

( ) Supervisor de Atendimento

Há quanto tempo esta na função?

( ) até 1 ano

( ) 2 a 5 anos

( ) 6 a 10 anos

( ) Feminino

( ) 40 a 50 anos

( ) mais de 50 anos

Quais as suas perspectivas de carreira para os próximos 5 anos?

\section{Comunicação Interna}

Com qual freqüência você lê as notícias e novidades informadas pela instituição?
( ) Diariamente
( ) Dias alternados
) Semanalmente

) Às vezes

) Nunca

Com qual freqüência acessa o email coorporativo?

( ) Diariamente

) Às vezes

Gerente de Serviços

) Gerente Geral

) Gerente de Negócios

) 11 a 20 anos

) Mais de 20 anos

) Superior Completo
Pós-graduação
) Mestrado/Doutorado

) Superior Completo
) Pós-graduação
) Mestrado/Doutorado

) Superior Completo
) Pós-graduação
) Mestrado/Doutorado

) 11 a 20 anos

) Mais de 20 anos

) Divorciado/Separado
) Viúvo 
( ) Dias alternados

$$
\text { ) Semanalmente }
$$

) Nunca

As notícias apresentadas/divulgadas pela instituição são de fácil compreensão?

( ) Sim

( ) Não

Caso sua resposta seja "Não", o que poderia ser feito para melhorar:

No seu entendimento as metas e objetivos da Instituição estão bem definidos?

( ) Sim ( ) Não

Caso sua resposta seja "Não", o que poderia ser feito para melhorar o entendimento:

Avalie os canais de comunicação interna disponibilizados pela Instituição financeira, sendo:

1 - Muito Insatisfeito

2 - Insatisfeito

3 - Pouco Satisfeito

4 - Satisfeito

5 - Muito Satisfeito

$\begin{array}{ll}( & \text { ) Agência de Notícias } \\ ( & \text { ) Email Coorporativo } \\ ( & \text { Aplicativo Responde } \\ ( & \text { ) Centrais de Atendimento } \\ ( & \text { Instruções Normativas } \\ ( & \text { ) Mensagens Instantâneas } \\ ( & \text { TV Institucional } \\ ( & \text { Revista institucional } \\ ( & \text { ) Ouvidoria Interna } \\ \text { Ecoa }\end{array}$

Caso tenha atribuído alguma nota de 1 a 3, o que poderia ser mudado para melhorar o canal de comunicação interna:

\section{Motivação}

Ao preencher o questionário considere o grau de motivação conforme abaixo:

1 - Muito Desmotivado

2 - Desmotivado

3 - Pouco Motivado

4 - Motivado

5 - Muito Motivado

Como se sente sobre:

As oportunidades de ascensão profissional:

As ações de formação profissional desenvolvidas:

Oportunidades de desenvolver novas competências:

A divisão das atividades na agência 
$O$ atual cargo que exerce:

Os objetivos e metas da agência:

A comissão exercida e a remuneração recebida

Você se considera hoje no trabalho uma pessoa

\section{Treinamento}

Qual tipo de curso/treinamento você mais utiliza?

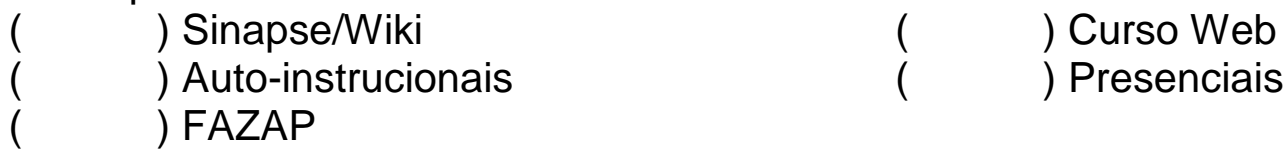

Qual você acredita ter melhor aproveitamento de aprendizado?
( ) Sinapse/Wiki
) Curso Web
) Auto-instrucionais
) Presenciais
) FAZAP

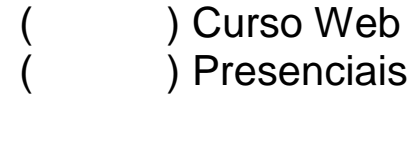

Quando foi a ultima vez que fez que você participou de um curso/treinamento presencial?

$\begin{array}{ll}(\quad) \text { até um mês } \\ \text { ( } & \text { a } 4 \text { meses } \\ & 5 \text { a } 7 \text { meses }\end{array}$

Existe incentivo da administração da agência para a cultura de treinamento?
( ) Sim
( ) Não

Quanto tempo você dedica para cursos/treinamentos por semana?

$\begin{array}{ll}(\quad) & 1 \text { hora } \\ (\quad) & \text { a } 3 \text { horas } \\ ( & \quad 4 \text { a } 5 \text { horas }\end{array}$

Hoje você se sente treinado para exercer sua função?

( ) Sim ( ) Não

Caso sua resposta seja "Não", o que seria necessário a instituição poderia fazer para você se sentir seguro no exercício da sua função?

\section{Clima organizacional / Liderança}

Você tem a liberdade de expressar opiniões diferentes/contrárias às de seu chefe direto no que diz respeito ao andamento dos trabalhos na sua agência/setor?

( ) Sim ( ) Não

Sua equipe de trabalho é motivada e sempre busca objetivos comuns?

( ) Sim () Não

Caso a resposta seja "Não", você pode citar um motivo:

Você gosta e procura participar das decisões que afetam o trabalho na sua agência/setor?

( ) Sim ( ) Não

Caso a resposta seja "Não", você pode citar um motivo: 
A parcela de poder de decisão e autonomia incluídas em seu trabalho são suficientes para desenvolver atividades sob sua responsabilidade?

( ) Sim ( ) Não

Caso a resposta seja "Não", você pode citar um motivo:

Você sente que seu trabalho é estimulante e motivador.

( ) Sim ( ) Não

Caso a resposta seja "Não", você pode citar um motivo:

A comunicação verbal é facilmente compreendida na sua agência?

( ) Sim ( ) Não

Caso a resposta seja "Não", você pode citar um motivo:

Você sente que têm seu potencial devidamente reconhecido?
$\left(\begin{array}{l}\text { ) Sim } \\ \text { ( ) Não }\end{array}\right.$

Caso a resposta seja "Não", por quê?

As pessoas têm tranqüilidade para executar suas tarefas dentro de um ritmo normal, com distribuição eqüitativa de carga de trabalho entre os colegas. $\mathrm{O}$ ambiente de trabalho não é tenso.

( ) Sim ( ) Não

Caso a resposta seja "Não", você pode citar um motivo:

Você pode dizer sinceramente que tem uma boa visão sobre as metas e objetivos da sua agência?

( ) Sim ( ) Não

Caso a resposta seja "Não", você pode citar um motivo:

Você Tem absoluta certeza daquilo que esperam de você e de onde pode chegar nessa instituição?

( ) Sim ( ) Não

Caso a resposta seja "Não", você pode citar um motivo:

Seu superior imediato aceita facilmente as sugestões que você dá?

( ) Sim ( ) Não

Caso a resposta seja "Não", você pode citar um motivo:

Seu superior imediato se manifesta positivamente quando demonstra um desempenho acima do esperado?

( ) Sim ( ) Não

Caso a resposta seja "Não", você pode citar um motivo:

Seu superior imediato se preocupa em manter seus subordinados informados sobre as coisas que possam afetar o trabalho na agência/setor?

( ) Sim ( ) Não

Caso a resposta seja "Não", você pode citar um motivo:

As mudanças são comunicadas e explicadas com antecedência?

( ) Sim ( ) Não

Caso a resposta seja "Não", você pode citar um motivo: 
As ordens recebidas vêm acompanhadas da informação necessária a execução do trabalho?

( ) Sim ( ) Não

Caso a resposta seja "Não", você pode citar um motivo:

O relacionamento no ambiente de trabalho é amigável?

( ) Sim () Não

Caso a resposta seja "Não", você pode citar um motivo:

Existe competitividade exagerada no seu ambiente de trabalho?

( ) Sim ( ) Não

Caso a resposta seja "Sim", você pode citar um motivo: 